\title{
Spatiotemporal Variability of Precipitation and Its Statistical Relations to ENSO in the High Andean Rio Bogotá Watershed, Colombia
}

\author{
NORBERT ANSELM ${ }^{\mathrm{a}}$ \\ Institute of Geographical Sciences, Freie Universität Berlin, Berlin, Germany \\ OSCAR ROJAS \\ Departamento de Química y Biología, Universidad del Norte, Barranquilla, Colombia \\ GRISCHA BROKAMP \\ Botanischer Garten und Botanisches Museum Berlin-Dahlem, Freie Universität Berlin, Berlin, Germany \\ BRIGITTA SCHÜTT \\ Institute of Geographical Sciences, Freie Universität Berlin, Berlin, Germany
}

(Manuscript received 18 July 2019, in final form 23 July 2020)

\begin{abstract}
Sustainable management of biodiversity requires a thorough understanding of local climate and weather, particularly in areas where ecosystems have been degraded and where life is highly adapted to or dependent on narrow ecological niches. Furthermore, society, economy, and culture of urban agglomerations are directly affected by the quality and quantity of services provided by adjacent ecosystems, which makes knowledge of regional characteristics and impact of climate variability crucial. Here, we present precipitation data from six meteorological stations spread across several orographic zones of the eastern Andes in the surroundings of Bogotá, Colombia's biggest urban agglomeration. The time series of rainfall data are analyzed statistically, examined regarding the occurrence of cyclicity in relation to ENSO, and correlated to the multivariate El Niño-Southern Oscillation index (MEI). Results offer no conclusive ENSO-related cycles but show that data of most of the stations are marked by annual or semestral cyclicity. There is no straightforward correlation between MEI and monthly precipitation values, and neither filtered nor lagged values showed any conclusive and significant correlation. Stations within the same orographic zones do not necessarily bring forth comparable statistical results. Temporal and spatial properties of precipitation appear to result from micro- and mesoscale topoclimates rather than from ENSO variability.
\end{abstract}

KEYWORDS: Tropics; ENSO; Topographic effects; Spectral analysis/models/distribution; Time series

\section{Introduction}

The availability of moisture, whether in gaseous or liquid phase, is one of the fundamental environmental constraints to biotic life (Falkenmark and Mikulski 1994; Postel 2000). Availability of water heavily depends on precipitation to feed streamflows, ponds, or lakes; to recharge aquifers; or to supply flora and fauna with freshwater. Precipitation as a prominent part of the water cycle is predominantly driven by climate as a result of meridional and latitudinal fluxes (Kousky and Kagano 1981; Zhou and Lau 2001; Dai and Trenberth 2002; Liu and Alexander 2007). However, Earth's climate is strongly variable and an object of steady change and adaption (Thornton et al. 2014). Key to understanding the fluxes across great distances is knowledge on large-scale atmosphere-ocean interactions (Liu and Yang 2003; Liu and Alexander 2007).

a ORCID: 0000-0003-0367-6850.

Corresponding author: Norbert Anselm, n.anselm@fu-berlin.de

Earth Interactions is published jointly by the American Meteorological Society, the American Geophysical Union, and the Association of American Geographers.
Several such coupled land-ocean-atmosphere circulation systems (also referred to as teleconnections) are known, such as the North Atlantic Oscillation (NAO; Hurrell et al. 2001), the North Pacific Oscillation (PNO; Rogers 1981), the PacificNorth American Pattern (PNA; Douglas et al. 1982), and El Niño-Southern Oscillation (ENSO, Philander 1983; Rasmusson and Wallace 1983). These coupled land-ocean-atmosphere circulation systems have a significant impact on various biophysical (Ropelewski and Halpert 1987; Poveda et al. 2001b; Alexander et al. 2002; Waylen and Poveda 2002; Cadena et al. 2006; Ramos da Silva et al. 2008; Mantilla et al. 2009; Poveda et al. 2011; Iizumi et al. 2014; Miralles et al. 2014; Capotondi et al. 2015) and socioeconomic (Baylis et al. 1999; Pabón and Torres 2007; Aceituno et al. 2009; Hoyos et al. 2013; Brando and Santos 2015; Abril-Salcedo et al. 2016; Vargas et al. 2018) conditions in many parts of the world. ENSO is one of Earth's strongest and, presumably, the most prominent of such year-to-year climate oscillations (Philander 1983; Rasmusson and Wallace 1983; Santoso et al. 2017; Yeh et al. 2018). In northwest South America, Peru and Ecuador are directly affected by irregularly occurring periodic variations in

Publisher's Note: This article was revised on 23 September 2020 to correct the IDEAM (2017) reference, which was incorrect when originally published. 
winds and sea surface temperatures over the tropical eastern Pacific Ocean, whereas Colombia is considered to be directly and indirectly impacted by ENSO severely (Bernal et al. 2007).

Colombia is in multiple ways complex and unique, as is its geographical setting: The country is encircled by two oceans (Pacific Ocean and Caribbean Sea), and encompasses parts of the Amazon basin that produces an atmospheric high in boreal summer and hosts large parts of the Amazon's headwater areas (Latrubesse et al. 2005). Topographically, the country is intersected by two (south) to three (north) mountain ranges of the Andes, striking northwest with peaks up to $5000 \mathrm{~m}$ MSL. Due to the high mean elevation in large parts of the country, there are strong land-atmosphere feedbacks (Poveda et al. 2014).

In Colombia, the hydrological response to ENSO is highly complex and nonlinear (Marin and Ramírez 2006), ranging from large to continental scale (Bedoya-Soto et al. 2018) and covering a time range between diurnal cycles (Poveda et al. 2005) to interannual time scales (Hoyos et al. 2018). The Colombian topography is characterized by a mosaic of small sections with varying relations to ENSO-like phenomena. On the Pacific coast, for instance, the tremendous amounts of rainfall, which are induced by a low-level westerly jet that diminishes during positive ENSO phases (Poveda and Mesa 2000) and the erosivity of rainfall is reported to be increased during negative ENSO phases (Poveda et al. 2001a; Romero et al. 2007). Correspondingly, the streamflow is strongly dependent on ENSO phases (Poveda and Mesa 1997; Gutiérrez and Dracup 2001; Poveda et al. 2001a). On the regional scale, annual rainfall is reported to increase during La Niña and decrease during El Niño in the region of Bogotá (Velandia 2016).

Besides hosting numerous unique and endemic species and outstanding ecosystems (Ulloa et al. 2017), high mountain ecosystems are known for the vital ecosystem services they provide, with water regulation and supply as probably the most important one given the large number of people that depend on them (Briner et al. 2012).

The sensitivity of tropical high mountain plants to climatic variability has not been evaluated in depth, though it is known that patterns of seasonal plant development (phenological niche) and determinants in the replacement of individuals within a plant community (regeneration niche) are strongly affected by seasonality and climatic variability (Grubb 1977); changes in the interannual variation in precipitation may alter species-richness patterns or the composition of plant communities through increased drought stress and seedling mortality. Lopez and Kursar (2007) found certain plant species to be more dominant in the tropical flood forests of Darien (Panama) and explained it by a negative impact of the El Niño phenomenon on the survival of seedlings of various species. This negative impact on plant communities has been documented also in other regions of America, such as Patagonia (Suarez et al. 2004; Suárez-Vidal et al. 2017), eastern Brazil (Williamson et al. 2000; Rolim et al. 2005), Barro Colorado-Panama (Condit et al. 1995), and Costa Rica (Chazdon et al. 2005) as well as in other regions of the world (Allen et al. 2010).

In this study we analyze the monthly precipitation from six rainfall gauging stations across several orographic zones within the watershed of the Rio Bogotá located in the eastern branch of

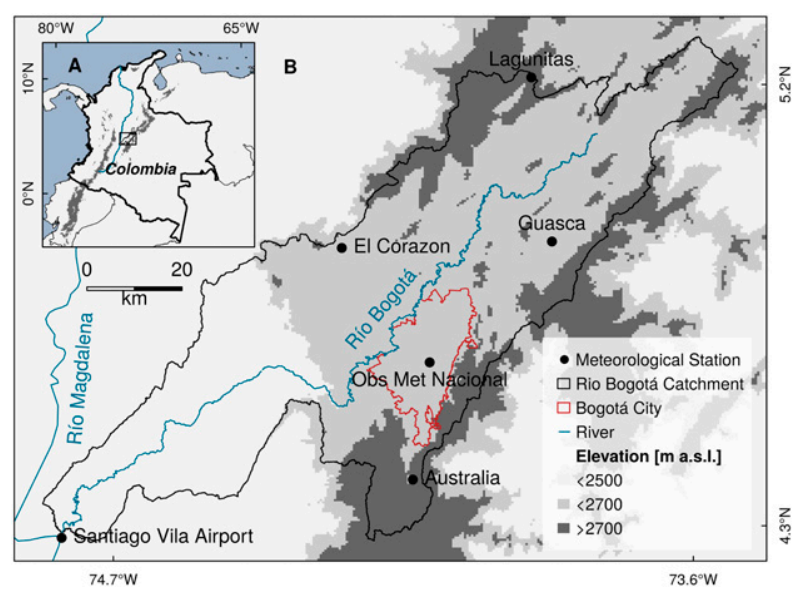

FIG. 1. Study area and location the meteorological stations. (a) Overview map. (b) Rio Bogotá drainage basin and distribution of rain gauges. See Table 1 for detailed information [elevation data derived from Global Multi-resolution Terrain Elevation Data (GMTED; Danielson and Dahl 2011)].

the Andes (Fig. 1). We examine the spatial and temporal variability of the rainfall data and their seasonal variation as well as the statistical relations to the ENSO phenomena. We aim to search for the possible existence of trends and time patterns in the rainfall data and to comprehend the hydroclimatic characteristics of a region identified as one of the most critically endangered biodiversity hot spots on Earth (Abud et al. 2017).

Our results may act as a frame of reference in the formulation of conservation strategies and regional management plans and, by doing so, may help us to face the threats of global environmental change. The results may also contribute to improve regional risk (natural disasters and human health) and resource management and by that, further, a more sustainable management and conservation of the ecosystem's biodiversity and hydrobiological resources.

\section{Study area}

The study area is located in the center of the Colombian Andes (Fig. 1a). It covers the Sabana de Bogotá, which represents the southwestern part of an Andean plateau-Cundiboyacense (Montoya Arenas and Reyes Torres 2005), also referred to as Altiplano, and the corresponding capital, the encompassing mountain ranges of the Cordillera Oriental, and a little fraction of the Rio Magdalena valley in the southwest (Fig. 1b). In this altitudinally lowest part the study area is located at approximately $280 \mathrm{~m} \mathrm{MSL}$, while the highest Andean peaks reach up to $3500 \mathrm{~m}$ MSL here. The majority of the study area is located on the Altiplano, ranging in altitude between 2500 and $2700 \mathrm{~m}$ MSL. The Altiplano corresponds to an intra-Andean basin that is uplifted to today's level since the Oligocene when the plates of South America, Nazca, and the Caribbean converged (Hoorn et al. 1995; Montoya Arenas and Reyes Torres 2005). Within roughly the last 3 million years, this upheaval caused high morphodynamics for approximately the last 3 million years and temporally and spatially variable sedimentary environments (fluvial, glacial, colluvial, and lacustrine) formed vast 


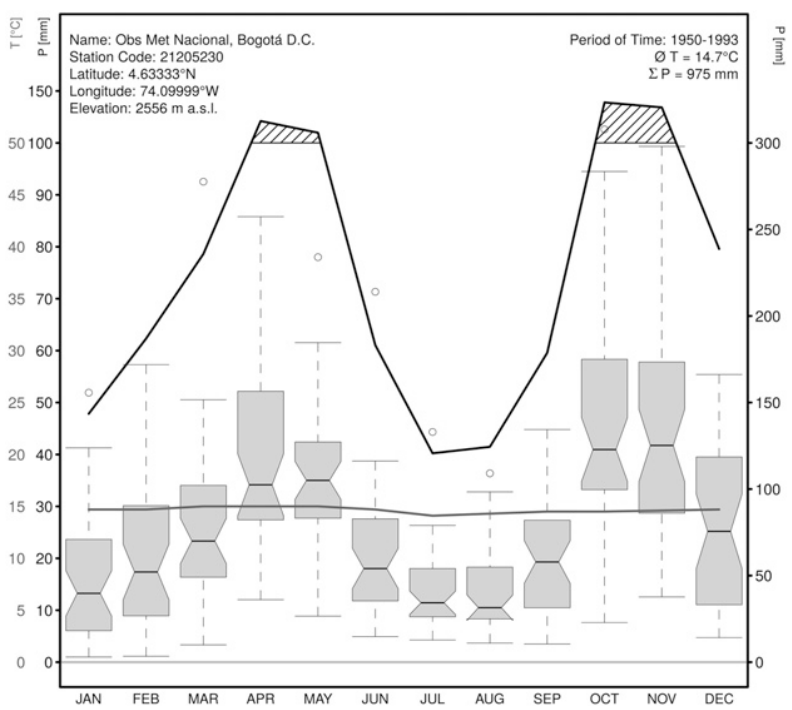

FIG. 2. Climate data of Observatorio Meteorológico Nacional, Bogotá (IDEAM 2017), (located at $4.63^{\circ} \mathrm{N}, 74.09^{\circ} \mathrm{W}$ at $2556 \mathrm{~m}$ MSL in the city center of Bogotá). Period of time is 1950-93 with a mean annual temperature of $14.7^{\circ} \mathrm{C}$ and an average sum of $975 \mathrm{~mm}$ rainfall per annum. The left-hand axis indicates the labeling of the Walter Lieth plot; right-hand axis refers to the boxplots.

areas of the recent high plain of Bogotá (Helmens and van der Hammen 1994; Andriessen et al. 1993).

The climate in the Sabana de Bogotá is classified as Cfb in the Köppen-Geiger classification (Köppen 1923; Kottek et al. 2006), corresponding to a warm temperate, year-round humid climate with warm summers. However, this classification is distorted by the relatively high mean altitude of $2600 \mathrm{~m}$ MSL of the Sabana de Bogotá close to the equator. The annual temperature in Bogotá averages $14.7^{\circ} \mathrm{C}$ (for the period $1950-93$ ), with little to no variability throughout the year, while most of the study area is subject to a bimodal pattern of monthly precipitation sums with two rainy seasons, the first occurring in the months March and April and the second in October and November (Fig. 2). Both rainy seasons are comparable in intensity and extension. The main dry season has its minimum precipitation values in July and August, while a secondary and less distinct dry season emerges in January. In higher altitudes the bimodal pattern of monthly precipitation sums still occurs, but with a weakened midyear dry season and a less pronounced rain season in September and October (Guhl Nimtz 1982).

Given that approximately one-fifth of Colombia's population is living in the Altiplano [National Administrative Department of Statistics (Departamento Administrativo Nacional de Estadístico) 2012] and industrialized agriculture in the peri-urban areas is increasing the impact on water demand (Antonio-Fragala and Obregón-Neira 2011), availability of freshwater is crucial in this region.

Bogotá's freshwater originates from the slopes of the neighboring Andean mountains, covered by extensive páramo and similar vegetation, which functions as a "natural water tower" for the capital (Buytaert et al. 2004; Buytaert and Breuer 2013) that provides numerous reservoirs in the Altiplano with water. Most freshwater is taken either from these reservoirs (Corporación Autónoma Regional de Cundinamarca 2017) or from wells throughout the Sabana de Bogotá (Uscátegui 1992).

\section{Methods and data}

\section{a. Data}

Daily precipitation data of six weather stations were obtained from the Instituto de Hidrología, Meteorología y Estudios Ambientales (IDEAM) in Bogotá. These stations were chosen, since they meet the following requirements: (i) requested data from IDEAM were available, (ii) temporal coverage was $\geq 30$ years, (iii) amount of missing data (in years) minus total coverage must be $>30$ years, and (iv) altogether evenly distributed throughout the research area. Table 1 offers detailed information on the station locations and obtained data. The stations' monthly precipitation values were calculated from daily values. Data of all stations had missing values of various temporal extent and accumulation. Special treatment in regard to missing data was not performed since the observation periods of daily rainfall data were considered to cover a sufficiently long time span.

Single-month values were used for analyses instead of typical trimestral scheme of rainfall data (MAM, JJA, SON, DJF), because there are months that can be classified as transition period between dry season and rainy season: September, for example, would be part of a trimestral period that incorporates the rainy-season months October and November, while the data clearly show that September is part of the dry season (Fig. 3). Thus, single-month values were preferred for analyses.

TABLE 1. Meteorological station locations, time series used, and portion of missing data.

\begin{tabular}{lcccccccc}
\hline \hline \multicolumn{1}{c}{ Name } & \multicolumn{3}{c}{ Altitude } & & \multicolumn{2}{c}{ Missing data } \\
\cline { 3 - 8 } & Lon $\left({ }^{\circ} \mathrm{E}\right)$ & Lat $\left({ }^{\circ} \mathrm{N}\right)$ & $(\mathrm{m} \mathrm{MSL})$ & Landscape & Start & End & Percentage & No. of years \\
\hline S. V. Airport & -74.798 & 4.275 & 286 & Lowland & 2 Aug 1960 & 31 Dec 2015 & 5.03 & 2.8 \\
Lagunitas & -73.907 & 5.214 & 3100 & Highland & 14 Mar 1985 & 30 Apr 2016 & 3.51 & 1.1 \\
Australia & -74.132 & 4.394 & 3050 & Highland & 13 Mar 1985 & 31 May 2017 & 2.41 & 0.8 \\
El Corazon & -74.266 & 4.866 & 2750 & Altiplano & 26 Jul 1974 & 31 Dec 2016 & 2.57 & 1.1 \\
Guasca & -73.868 & 4.879 & 2580 & Altiplano & 1 Jan 1975 & 31 Aug 2016 & 7.74 & 3.2 \\
Observatorio & -74.099 & 4.633 & 2556 & Altiplano & 1 Jan 1950 & 30 Dec 1993 & 4.36 & 1.9 \\
$\quad$ Meteorológico Nacional & & & & & & & & \\
\hline
\end{tabular}




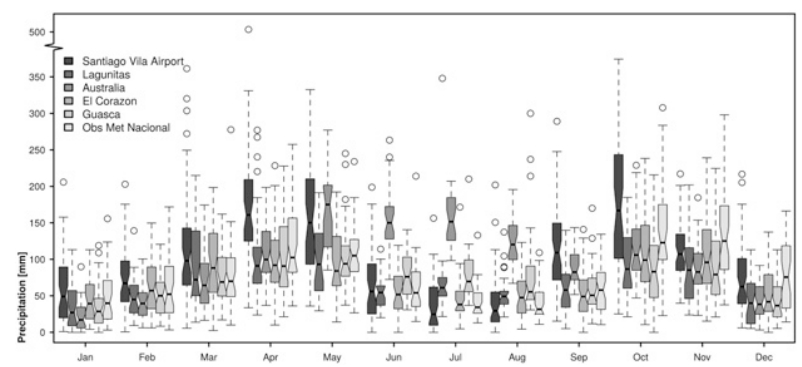

FIG. 3. Rainfall variability in the area of the Sabana de Bogotá: Monthly precipitation (boxplots) per station in the area of the Sabana de Bogotá. Detailed information on the used stations can be found in Table 1 .

\section{b. Statistical methods for precipitation analysis}

Basic statistical analyses and autocorrelation tests were applied. The nonparametric, robust Spearman's rank correlation coefficient test (Spearman 1904) was applied in order to detect (monotonic) trends because precipitation data is rarely distributed normally in such heterogeneous terrain (Buytaert et al. 2006a,c; Bookhagen and Strecker 2008; Celleri et al. 2007). The statistical analysis was complemented by the KwiatkowskiPhillips-Schmidt-Shin test (KPSS) for stationarity around the trend (Kwiatkowski et al. 1992).

The analyses of the multivariate ENSO index (MEI; Wolter and Timlin 2011) was applied. Here, the main variables influenced by and influencing positive or negative phases of ENSO are incorporated. These are (i) sea level pressure, (ii) zonal and (iii) meridional components of the surface wind, (iv) sea surface temperature, (v) surface air temperature, and (vi) total cloudiness fraction of the sky. MEI is the first unrotated principal component of the 6 input variables calculated from 12 sliding bimonthly values for 6 spatially filtered clusters (Wolter and Timlin 1993). Monthly precipitation data were correlated to monthly MEI in total and using a moving filter with a kernel of 12 months.

\section{c. Wavelet analysis}

Monthly precipitation values were decomposed into timefrequency space using continuous wavelet transform (CWT). Wavelet transform can be used to analyze time series that contain power at various different frequencies (Daubechies 1990). Therefore, a signal (time series $x_{n}$ ) and a wavelet function $\left[\Psi_{0}(\eta)\right]$ that depends on a nondimensional time parameter were required. In the case of the used Morlet wavelet, the function had a zero mean and consisted of a plane wave (sinusoid) that is modulated by a Gaussian. The second-order exponential decay of the signal is an optimal time localization during transformation and provides information of amplitude and phase (Hadjileontiadis 2018). Hence, CWT results are clear graphical representations of the power spectra changes with time (Kestin et al. 1998).

According to Meyers et al. (1993), Morlet wavelets are a common choice in meteorology, in particular for ENSO signal processing (Gu and Philander 1995). Wavelet transforms have the advantage to be independent from stationary processes, and hence, work for stationary as well as nonstationary data (Torrence and Compo 1998; Mertins 2001).
All analyses have been conducted in R 3.4 ( $\mathrm{R}$ Core Team 2018) using the following packages: tseries (Trapletti and Hornik 2017), zoo (Zeileis and Grothendieck 2005), xts (Ryan and Ulrich 2017), nortest (Gross and Ligges 2015), hydroTSM (Zambrano-Bigiarini 2017), and dplR (Bunn et al. 2018).

\section{Results}

\section{a. Minimum and maximum monthly rainfall}

Each station is considered independently. Hence, numerically or hierarchically ordering the resulting figures is neglected, and the authors just grouped them with regard to the topographical location (Lowland, Highland, and Altiplano).

Analyzed precipitation data from the six weather stations were surprisingly heterogeneous in regard to the course of the year. Below we provide a detailed description of the time series of the Australia station (Fig. 5a). Results from the other stations' data (Figs. 4-9) are reported if deviating notably from Australia only.

At Australia station, the annual distribution of rainfall is generally bimodal with two rainy seasons per year, the first one of which is the minor one followed by a major second rainy season. A major dry season occurs as a pronounced annual minimum and a minor dry season appears as a brief depression between the two rainy seasons (Figs. 3 and 5a).

The maximum monthly rainfall recorded during the period analyzed (from March 1985 to May 2017) amounts to $277.1 \mathrm{~mm}$ and occurred in May 2000. No rainfall $(0 \mathrm{~mm})$ was recorded at Australia in January 2016. The precipitation sums do not show a significant linear trend either at Australia (slope: 0.16, intercept: -215.86$)$ or at any of the other stations

Apart from some peaking monthly precipitation amounts at Australia station, for example, in May 1994, 2003, and 2000, there is not much variability in the data. In the other stations' time series several phases of relative minima or maxima can be identified: for example, Lagunitas (Fig. 6a) shows two phases of increased monthly precipitation sums in the period 2005-13. For the Observatorio Meteorológico Nacional station (Fig. 8a) in the years 1981-83 increased amounts of monthly precipitation occur, while in 1983 and 1986 they clearly are below average. At El Corazon station, two phases of lower monthly rainfall sums are identified between 1989 and 1995 and in 1998. Relative maxima of monthly rainfall sums occur here in the years 2010-12 (Fig. 7a).

In the case of the Santiago Vila Airport station (Fig. 4a), various phases of relatively low monthly rainfall sums are found in 1973, 1974, and 1976, while maxima of monthly rainfall occur in 1971 and in the period 1979-84.

In spite of the relatively large amount of missing values (7.74\%) for the Guasca station (Fig. 9a), relative maxima of monthly rainfall are identified in the period 1979-81, in 1996, and in 2010-13. Phases of relatively low monthly rainfall amounts could be identified for 1977-78, 1983-84, and 1993-95. However, data from the stations do not show any significant trend.

\section{b. Descriptive statistics of monthly precipitation data}

An overview on the basic statistics of the tested weather stations from the Sabana de Bogotá offers Table 2. Highest 


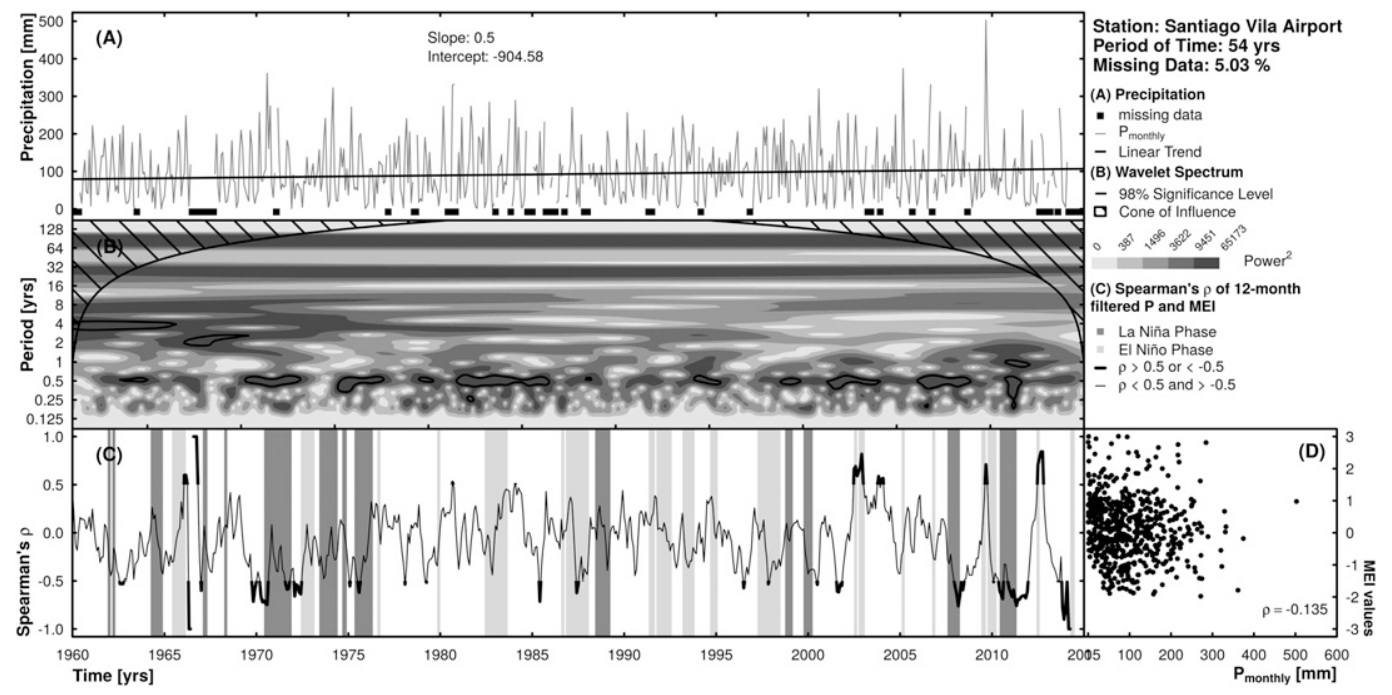

FIG. 4. (a) Time series of monthly precipitation sums at station Santiago Vila Airport (Lowland), located at the outlet of the Rio Bogotá basin, southwest of the city of Bogotá. The ordinate shows the amount of precipitation (in $\mathrm{mm}$ ). The linear trend of rainfall amount is indicated by the bold black line, and missing values are indicated by black blocks at the bottom of (a). (b) Continuous wavelet spectrum of the time series. Significant spectra (98\%) are denoted by black circles. The ordinate indicates the period (in years). (c) Coefficient of correlation (Spearman's $\rho$ ) of the monthly rainfall amounts and the MEI using a 12-month filter. The ordinate covers values from -1 to 1 , representing Spearman's $\rho$. Coefficients $>0.5$ or $<-0.5$ are denoted using a bold black line. The abscissa depicts the time (in years) and is valid for (a)-(c). (d) Spearman's $\rho$ of unfiltered rainfall amounts and MEI phases.

values of maximum monthly precipitation are found at the station Santiago Vila (S. V.) Airport $502.7 \mathrm{~mm}$ (April 2010). Highest monthly rainfall amounts occur in Australia and Santiago Vila Airport averaging $98.3(\operatorname{std~dev}=58.48, n=396)$ and $98.02 \mathrm{~mm}$ ( $\operatorname{std} \mathrm{dev}=74.42, n=672)$, respectively.

The stations Lagunitas and Australia are both located on the mountain flanks that surround the Sabana de Bogotá (Fig. 1a). Lagunitas station, located at $3100 \mathrm{~m}$ MSL on the northern flanks of the Sabana de Bogotá, has a monthly mean rainfall amount of $71 \mathrm{~mm}$ ( $\mathrm{std} \mathrm{dev}=48.83, n=384)$. It shows a kurtosis of 3.87 , which is the highest value obtained. Australia station, located on a mountain range at the southern flanks of the Sabana de Bogotá, has the lowest positively skewed value distribution of all tested stations. Here, the kurtosis value of the monthly rainfall data amounts -0.48 , which overall is the lowest and the only negative one retrieved.

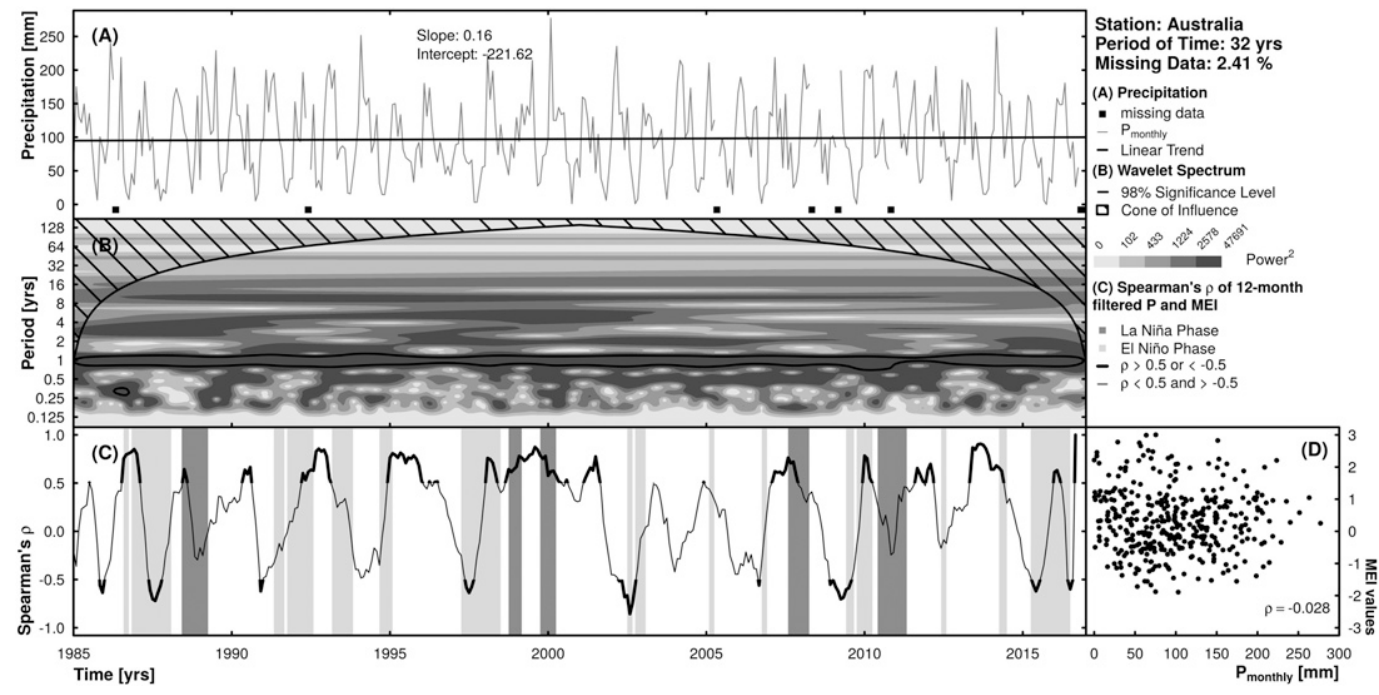

FIG. 5. As in Fig. 4, but for station Australia (Highland), located in the mountains surrounding the Sabana de Bogotá at the southern edge of the Rio Bogotá basin, south of the city of Bogotá. 


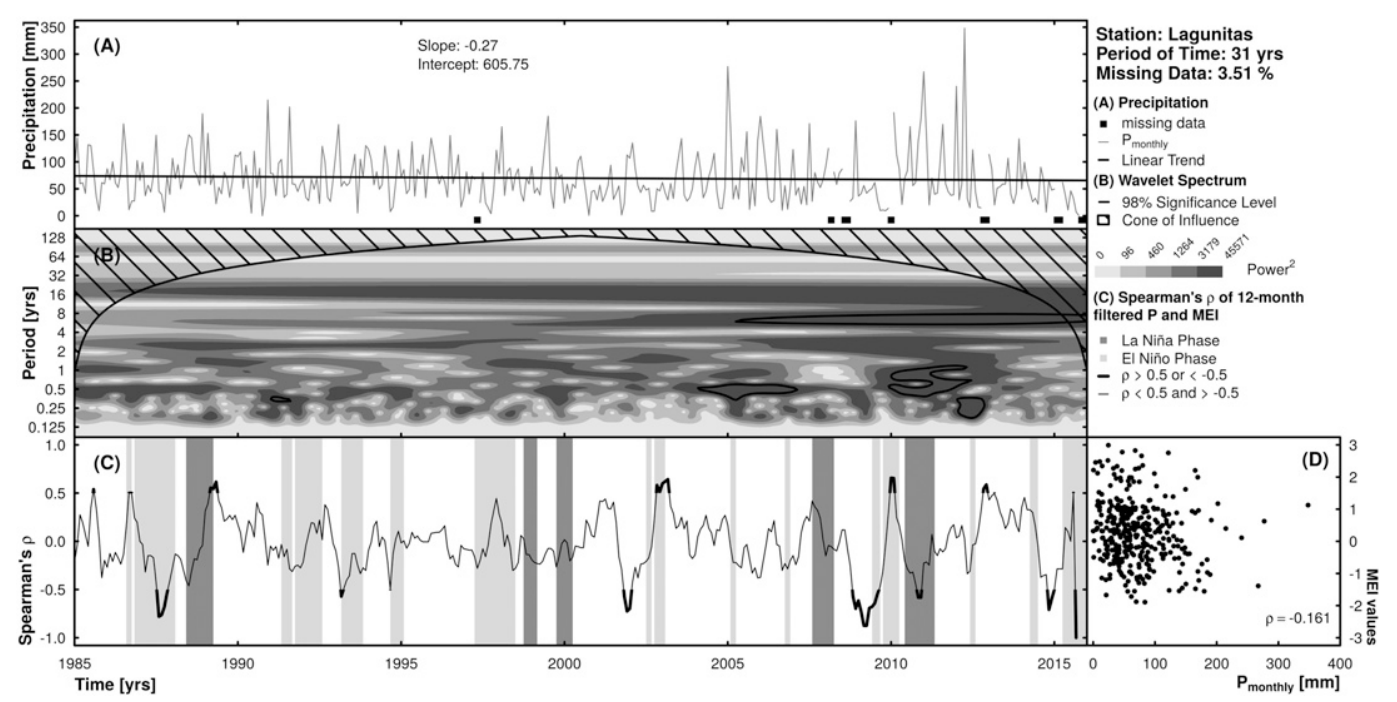

FIG. 6. As in Fig. 4, but for station Lagunitas (Highland), located in the mountains surrounding the Sabana de Bogotá at the northern edge of the Rio Bogotá basin, north of the city of Bogotá.

Australia's mean monthly precipitation totals $98.3 \mathrm{~mm}$ (std $\operatorname{dev}=58.48, n=396)$.

The stations El Corazon, Guasca, and Observatorio Meteorológico Nacional are located within the Sabana de Bogotá (Fig. 1a): El Corazon and Guasca stations are located in the northwest and northeast of Bogotá, respectively, and Observatorio Meteorológico Nacional station lies directly in the city center. El Corazon has the lowest maximum monthly rainfall value $(239.1 \mathrm{~mm})$ of these three stations in the observation period and the mean monthly precipitation value is $72.15 \mathrm{~mm}$ ( $\mathrm{std} \mathrm{dev}=47.65, n=516$ ). Guasca station shows a comparable mean monthly rainfall value of $73.33 \mathrm{~mm}$ ( $\operatorname{std} \operatorname{dev}=47.21, n=504)$, but Guasca station has a 5-timeshigher kurtosis (2.09) in comparison to El Corazon station (0.42). Observatorio Meteorológico Nacional has the highest maximum (307.8 mm), minimum (3 mm), and mean $(81.72 \mathrm{~mm}$, std $\operatorname{dev}=56.41, n=528)$ monthly precipitation sums of all stations located on the Altiplano.

Spearman's rank correlation coefficient $(\rho)$ was calculated for all stations' monthly rainfall sums (Table 3 ). The following station pairs indicate weak, linear, and positive relationships: (i) Guasca and Australia, (ii) Guasca and Lagunitas, and (iii) Observatorio Meteorológico Nacional to all other stations but Australia (Table 3, $\star$ ). The KPSS test indicated nonstationarity for Guasca and Australia.

\section{c. Wavelet analysis on precipitation data}

The analysis of the CWT spectrum is presented in Figs. 4b-9b. The wavelet power spectrum shows the variance of monthly precipitation sums as time series across different time scales.

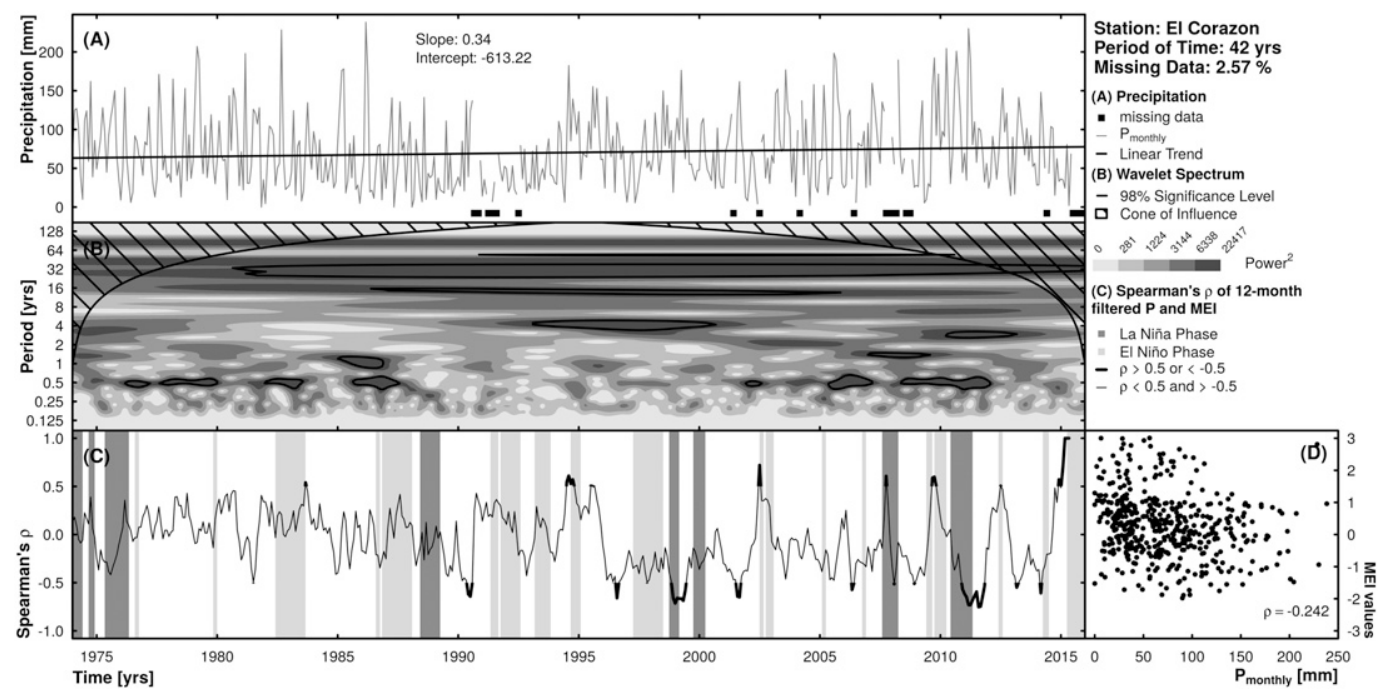

FIG. 7. As in Fig. 4, but for station El Corazon (Altiplano), located in the Sabana de Bogotá northwest of the city of Bogotá. 


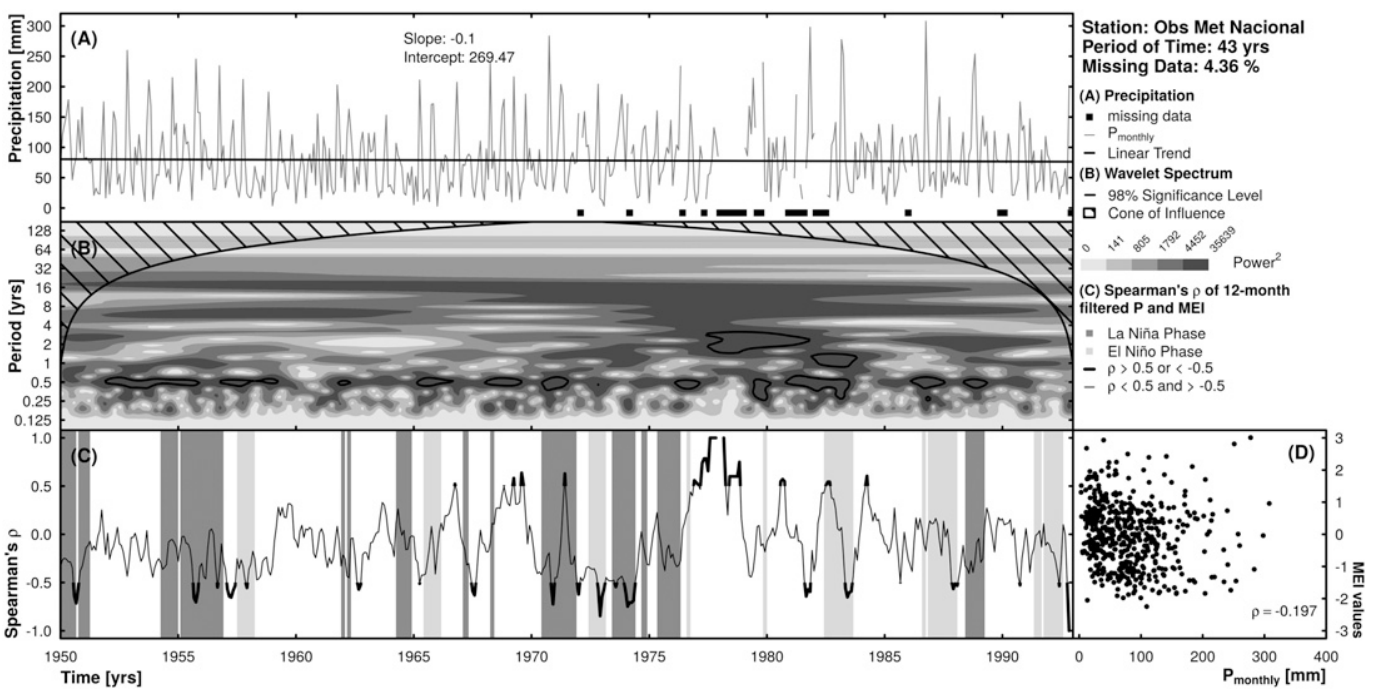

FIG. 8. As in Fig. 4, but for station Observatorio Meteorológico Nacional (Altiplano), located in the Sabana de Bogotá in the city center of Bogotá.

The abscissa is equivalent to the time series while the ordinate shows the period in years. At each position in the plot the set of wavelet coefficients influences the signal values (power spectrum) at a specific time scale: The darker the color, the higher the power spectra, and thus, the stronger the impact at that specific time scale. Significant areas of power are encircled by a black line (significance level of $98 \%$ ).

The CWT spectrum of monthly precipitation sums of the Santiago Vila Airport station reveals a prominent semestral cycle (Fig. 4b). Notably, there is one short period in 1981 significant on a 0.25 -yr scale. In addition, the first five years of the time series are characterized by a cycle on a $4-y r$ scale that is superseded by a $2-y r$ periodic cycle from
1966-68. In 2010, there is a short significant period on an annual cycle.

The CWT spectrum of the station Australia (period of 19852017 ) is presented in Fig. 5b. Besides a ubiquitous annual cycle along the entire time series there was no dominant specific periodic cycle. At the Lagunitas weather station, the first 20 years barely show any cyclicity (Fig. 6b), but in the periods 2004-07 and 2010-12, a semestral periodic cycle appears. The latter one is superposed by an annual cycle and succeeded by a 0.25 -yr cycle in 2012. From 2005 until 2016 a persistent period cycle occurs here on a 7-yr scale.

In the CWT of the station El Corazon a semestral period cycle is present, too, but not as prominent as at Santiago Vila

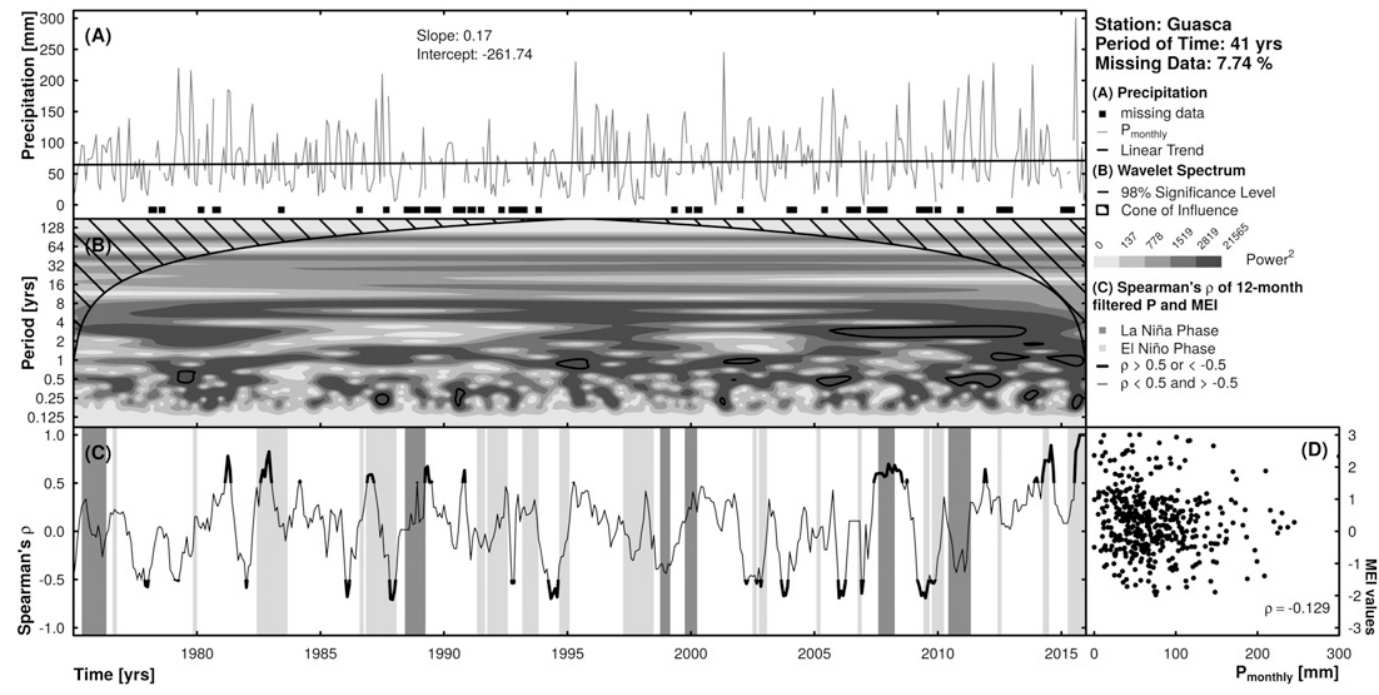

FIG. 9. As in Fig. 4, but for station Guasca (Altiplano), located in the eastern part of the Sabana de Bogotá, northeast of the city. 
TABLE 2. Basic statistic values of monthly precipitation data from six weather stations in the Sabana de Bogotá.

\begin{tabular}{|c|c|c|c|c|c|c|}
\hline & \multirow{2}{*}{$\begin{array}{l}\text { Lowland } \\
\text { S. V. Airport }\end{array}$} & \multicolumn{2}{|c|}{ Highland } & \multicolumn{3}{|c|}{ Altiplano } \\
\hline & & Lagunitas & Australia & El Corazon & Guasca & $\begin{array}{c}\text { Observatorio Meteorológico } \\
\text { Nacional }\end{array}$ \\
\hline$n$ & 672 & 384 & 396 & 516 & 504 & 528 \\
\hline $0 \%(\min )$ & 0 & 0 & 0 & 0 & 0 & 3 \\
\hline $25 \%$ & 40.6 & 38.2 & 52.8 & 33.5 & 39.4 & 37.1 \\
\hline $50 \%$ (median) & 83.9 & 59.2 & 91.6 & 64.0 & 64.9 & 71.9 \\
\hline $75 \%$ & 141.2 & 90.3 & 140.1 & 98.8 & 97.0 & 112.8 \\
\hline $100 \%(\max )$ & 502.7 & 348.0 & 277.1 & 239.1 & 300.0 & 307.8 \\
\hline Interquartile range & 100.6 & 52.1 & 87.3 & 65.3 & 57.6 & 75.7 \\
\hline Coefficient of variation & 0.76 & 0.69 & 0.59 & 0.66 & 0.64 & 0.69 \\
\hline Mean (first moment) & 98.02 & 71.00 & 98.30 & 72.15 & 73.44 & 81.72 \\
\hline Std dev (second moment) & 74.42 & 48.83 & 58.48 & 47.65 & 47.21 & 56.41 \\
\hline Skewness (third moment) & 1.10 & 1.54 & 0.43 & 0.87 & 1.25 & 1.15 \\
\hline Kurtosis (fourth moment) & 1.59 & 3.87 & -0.48 & 0.42 & 2.09 & 1.39 \\
\hline
\end{tabular}

Airport. It occurs in 1976-80, 1982-84, 1986-87, 2002, 2004, 2006-07, and 2008-12. An annual cycle is found for 1985-87 and $2008-10$, the latter merely on a 1.5 -yr scale. A 3 -yr period cycle is significant from 2010-13, a relatively long lasting 4-yr cycle can be identified from 1993 to 2001, and a 16-yr period cycle is shown from 1987-2006. Periodicity on longer time scales is not introduced here for methodic reasons (see discussion in section 5).

At the station Observatorio Meteorológico Nacional, a semestral periodicity is the most prominent one (Fig. 8b) identified for 1952-56, 1957-59, 1962, 1965-67, 1968-69, 1971, 1976-77, 1980, 1981-83, and 1986-89. From 1982 to 1984, an annual cycle is found that is preceded by a $2-y r$ cycle in the period 1977-82.

At the station Guasca (Fig. 9b), periodic features on a 0.25 yr time scale is identified for 1987, 1990, 2001, 2014, and 2015. On a semestral period cycle the years 1979, 2002, 2005-07, and 2011-13 is significant. An annual cycle occurs 1981, 1995-96, 2001-03, and 2012-16. The latter one is shortly interrupted in 2014 and superimposed by an event on a 2-yr scale. Except for one period cycle on a 4-yr scale lasting from 2006 to 2014, cycles on larger time scales were not found at Guasca.

\section{d. Relationship of multivariate ENSO index and precipitation values \\ In this section, only the results of Australia station are presented.}

A linear relationship between monthly rainfall amounts and parameter values of ENSO phases for the entire time series of the station Australia (Fig. 5d) is not found. In addition, Spearman's $\rho$ of -0.028 indicates a completely random relationship. In addition, the correlation between monthly rainfall amounts and parameter values of ENSO phases using a 12-month filter (Fig. 5c) shows periods that indicate robust correlation, but throughout the time series no coherent pattern appears.

The El Niño event in 1986-88 corresponds to positive as well as to negative values of $\rho$. The same applies for the strong El Niño event in 1997-98. The time from 1998 to 2002 is marked by positive $\rho$ values, during which period both El Niño and La Niña events occurred. The negative ENSO phase offers similar inconclusive results. Either the periods of correlation are very weak to uncorrelated or they are influenced by other ENSO phases. The other five stations analyzed in the frame of this study show similar results for MEI and monthly rainfall values (Figs. 4c-9c).

\section{Discussion}

The monthly precipitation sums of six weather stations across a range of three altitudinal classes (Lowland, Altiplano, Highland) in the environs of the Sabana de Bogotá were analyzed with basic statistics and tested for correlation among each other, cyclicity within the data, and correlation to the MEI values, which incorporates the six most important variables

TABLE 3. Spearman's rank correlation coefficient $(\rho)$ of the tested precipitation time series in the Sabana de Bogotá and adjacent areas. A star $(\star)$ indicates a weak, positive linear relationship.

\begin{tabular}{|c|c|c|c|c|c|c|}
\hline & $\begin{array}{c}\text { Santiago } \\
\text { Vila Airport }\end{array}$ & Lagunitas & Australia & El Corazon & Guasca & $\begin{array}{c}\text { Observatorio Meteorológico } \\
\text { Nacional }\end{array}$ \\
\hline Santiago Vila Airport & 1 & 0.38 & 0.12 & 0.47 & 0.24 & $0.52 \star$ \\
\hline Lagunitas & & 1 & 0.47 & 0.47 & $0.6 \star$ & $0.62 \star$ \\
\hline Australia & & & 1 & 0.21 & $0.59 \star$ & 0.16 \\
\hline El Corazon & & & & 1 & 0.45 & $0.50 \star$ \\
\hline Guasca & & & & & 1 & $0.53 \star$ \\
\hline Observatorio Meteorológico Nacional & & & & & & 1 \\
\hline
\end{tabular}


related to the various types of ENSO phases. The general annual pattern of monthly precipitation sums is bimodal except for Australia station. There is no simple linear trend in the rainfall sums, neither positive nor negative (Carmona and Poveda 2014), and most of the stations do not correlate among each other with regard to monthly rainfall values except for Observatorio Meteorológico Nacional. The CWT spectrum reveals no coherent and persistent temporal pattern in the precipitation that can be related to ENSO except for Australia. There is no correlation between MEI values and monthly precipitation sums-neither for the entire time series nor for 12-month filtered values (lagged and unlagged). This can be clearly seen in Figs. 4-9 (panels c and d). The overall $\rho$ value between -0.028 and -0.242 , and the 12 -month kernel with ambiguous $\rho$ values underpin this interpretation.

\section{a. Local variability}

Precipitation follows a bimodal pattern within the seasonal cycle for almost all stations (Fig. 3). The two distinct low rain seasons - a primary in boreal summer and a secondary in austral summer - coincide with the most distant position of the intertropical convergence zone (ITCZ), while during the northward and southward progression of the ITCZ the study area encounters its maxima of rainfall (Hastenrath 2002). The boreal summer low rain season is more distinct because the ITCZ is proceeding much farther northward (close to the Caribbean) than in austral summer, in which it barely passes the equator (García 1994). This agrees with the results for the stations situated in the Lowland and Altiplano (Guzmán et al. 2014), but the two stations in the Highland show a different pattern.

The transport of moisture through the three branches of the Andes follows a complex pattern. The Andean valleys are considered relatively dry areas (Arango et al. 2015) surrounded by areas of relatively high precipitation induced by the orographic uplift of Atlantic and Pacific winds (Martínez et al. 2003). The southeastern trade winds form a westerly jet (Choco jet) centered at $5^{\circ} \mathrm{N}$ after crossing the equator (Martínez et al. 2003; Poveda et al. 2014). These winds cause that western Colombia is one of the rainiest places globally (Poveda and Mesa 2000). However, as the Cordillera Occidental and Cordillera Central act as barriers, it is believed that only relatively small amounts of moisture are transported by an atmospheric pressure gradient from the Pacific to the Cordillera Oriental (Gallego et al. 2018). The biotic pump of atmospheric moisture (BiPAM) theory, as proposed by Makarieva and Gorshkov (2007), might serve as an explanation. It gives evapotranspirated water a more prominent standing within the hydrological cycle as it states that atmospheric pressure gradients are amplified if land is covered with large forested areas. There is no proof that this effect can be transferred across topographical barriers, such as the Cordillera Occidental and Cordillera Central, but the relatively short distance of around $300 \mathrm{~km}$ from the Pacific coastline to the Sabana de Bogotá and the abundant presence of the various types of mountain forests (Armenteras et al. 2003, 2011; Balthazar et al. 2015) along the pathway make it a feasible option. Given that the mountain forest ecosystems in the Andes have changed over the last decades dramatically (Armenteras et al. 2011; Lutz et al. 2013) and are still decreasing (Anselm et al. 2018) the BiPAM effect would weaken significantly.

While Lagunitas, located at the northern rim of the research area, shows clear rainfall minima during boreal summer, the monthly rainfall pattern at Australia, in the south of Bogotá, tends to follow a unimodal pattern. Australia station appears to be located in a transitional zone where during the low rain season an additional source of moisture occurs. With respect to this station's location (Fig. 1; at $3050 \mathrm{~m}$ MSL, very close to the continental water divide), there are several sources of moisture: (i) Convection in the Highlands is triggered by high solar radiation, and, hence, increased evapotranspiration rates. The resulting small-scale convection cells are determined by topography. Thus, variations in wind speed and wind direction induced by irregular relief and differences in exposition and altitude create topoclimates (Buytaert et al. 2006a,b). (ii) Convection might be determined by mechanical uplifting, most likely amplified be a diurnal valley circulation system (Roe 2005). (iii) The austral summer rainfall in the Amazon basin is closely related to the intensity of a high pressure system in the upper troposphere $(200 \mathrm{hPa})$. Coupled to the course of the ITCZ, the high pressure system moves northward in April, crosses the equator, and then turns to northwest reaching Venezuela and Colombia by June/July (Kousky and Kagano 1981). This effect coexists with (iv) squall lines generated along the northeastern coast of South America, which extend at various scales and propagate inland up to the Andes (Ramos da Silva et al. 2008). Thus, the eastern Andean slopes show annual rainfall amounts totaling up to $5000 \mathrm{~mm} \mathrm{yr}^{-1}$ (Montgomery et al. 2001) that are mainly a result of mechanical uplifting of low-level airflow by topography (Nobre et al. 1991). At least a fraction of the eastern plain's summer rainfall (Bernal et al. 2007) seems to compensate for the low rainfall amounts of the boreal summer at Australia.

\section{b. Implications of statistical results}

The statistical results from the analysis of the precipitation data from the weather stations in the Sabana de Bogotá did not show a significant difference between the stations in regard to their orographic position. Santiago Vila Airport station shows the highest maximum of rainfall sums in a single month (502.7 mm in April 2010), which is caused by a combination of strong evapotranspiration (Worden et al. 2007) and extensive convective rainfall events during the ITCZ passage (Hastenrath 2002; Hoyos et al. 2018). This agrees with a relatively large standard deviation of $74.42 \mathrm{~mm}$, an IQR of $100.6 \mathrm{~mm}$ and a leptokurtic kurtosis (1.59, which implies a heavy-tailed distribution) of the Santiago Vila Airport station's rainfall data. Hence, the portion determined by the mode is smaller (Westfall 2014) and the extreme values got more weight (on both sides). In combination with the highly positive skewed data (1.1) it indicates a large number of positive values with tendency to positive extreme values. The classification of skewness values follows (Bulmer 1979).

The weather stations located on the Altiplano are quite comparable regarding the quartiles, means, and standard deviations of their monthly rainfall data. Observatorio Meteorológico 
Nacional station shows slightly higher values among quartiles, mean, and standard deviation of monthly rainfall data, which may result from urban surrounding of this weather station. Huff and Changnon (1973) already show in the 1970s the urban impact on precipitation. The major drivers are considered to be city size, urban thermal effects, surface roughness, increase of dewpoints, aerosol concentration, and industrial nuclei generation (Huff and Changnon 1973; Dixon and Mote 2003; Shepherd 2005). On the contrary, aerosols are also reported to be responsible for an altered cloud formation. Pollution increases concentration of hydrometeors and cloud drops, leading to reduced drop size, smaller ice crystals, and smaller fall velocities (Borys et al. 2000).

The weather stations at Guasca and El Corazon show quite comparable rainfall values in regard to quartiles (except for maximum), mean, and standard deviation, although El Corazon is located on the western divide of the Rio Bogotá basin and Guasca lies close to the eastern divide (Fig. 1). Yet, the third and fourth moments of distribution (skewness and kurtosis) of rainfall differ strongly here. Monthly rainfall values in Guasca are highly positive skewed (1.25) and strongly leptokurtic, while the values from El Corazon are moderately positive skewed (0.87) and mesokurtic. Hence, the data from Guasca entails more by high values of monthly rainfall sums that the data from El Corazon. In comparison with these two stations, the third station situated in the Altiplano, Observatorio Meteorológico Nacional appears to take in an intermediate rank with regard to monthly rainfall amounts. But since here the monthly rainfall values are leptokurtic, highly positive skewed, and show both higher mean and standard deviation values than Guasca and El Corazon, the tails of the value's distribution have to be taken into account. Accordingly, in contrast to El Corazon the station Observatorio Meteorológico Nacional is characterized by a large number of high values of monthly rainfall sums. Lower monthly rainfall sum values found in El Corazon can be explained by the station's location (Fig. 1) as it is shielded to the west, north, and east by mountain ranges.

Both Highland weather stations differ strongly in their monthly rainfall characteristics: Monthly rainfall values at Lagunitas station are strongly leptokurtic (3.87) and highly positive skewed. Their mode is strongly influenced by extreme monthly rainfall values, although the mean monthly rainfall is low compared to the stations within the Sabana de Bogotá. A likely cause can be found in a leeward position of the station in Lagunitas station in a valley encircled by hogback-like mountain ranges running from northeast to southwest. Hence, high distribution tilt (skewness) and long tails of the distribution (kurtosis) indicate a unique, by mesoscale topoclimate controlled precipitation regime that varies strongly from the surroundings. It agrees with Poveda (2004), who states that precipitation in the Andes is less related to macroclimates than to vertical processes, which in return are vastly subject to topography.

In contrast, monthly rainfall values at Australia station have a platykurtic $(-0.48)$ and an almost symmetric $(0.43)$ distribution. The third and fourth moments of distribution and an average sum of $98.3 \mathrm{~mm}$ of monthly rainfall indicate outstanding monthly rainfall characteristics for Australia station. Platykurtic kurtosis reveals a well-balanced precipitation regime. Taking into account that contributions of fog and drizzle can add up to $7 \%$ of the precipitation input in the Cordillera Oriental (Cárdenas et al. 2017), the density curve of Lagunitas would become even more arching and most likely more symmetrical. This agrees with Jaramillo-Robledo and Chaves-Córdoba (2000) who report that the eastern Andean peaks show a different (unimodal) distribution of rainfall.

The majority of the air masses reaching the Sabana de Bogotá comes from east and northeast. These winds have an annual share of $13.7 \%$ and $17.4 \%$ (totaling $31.1 \%$ ), respectively. But throughout the year the distribution pattern is shifting because (i) the prominent portion of wind from the northeast is abating from July to September (most distant ITCZ) and turns into (ii) east-southeast winds from July to September; (iii) from October to April there is a significant amount of wind coming from the west that declines from April through to September, and (iv) a steady portion of northern winds mostly on the level of $\geq 10 \%(7.9 \%-14.0 \%)$ occurs throughout the year (Bernal et al. 2007).

According to the topography, northeast winds pass the plateau after crossing the cordilleras and so they are rather dry when reaching the respective weather station. The same applies for northerly, easterly, and-to a lesser extent-southeasterly winds since they all have to cross the cordilleras. Thus, westerly winds appear to be a considerable source of moist air transported to the Sabana de Bogotá. This agrees with high rainfall intensities in the equatorial western Andean range, which are rather related to the latitudinal component of tropical airflow (moisture transport) than to the zonal wind component of El Niño (Pineda and Willems 2018).

\section{c. Wavelet analysis on precipitation data}

\section{1) CyCles ON ENSO SCALES}

El Niño's impact on precipitation are traced for northern, western, and central parts of Colombia (Córdoba-Machado et al. 2015). La Niña brings an increased risk of flooding to Colombia, especially in the northern and eastern Andean foothills (Hoyos et al. 2013). Thus, the cycles of El Niño and La Niña [3-5 years according to Graham and White (1988); 2-7 years after Giralt et al. (2007)] might be found as significant power spectra of the rainfall data.

The significant wavelet power spectrum on a 4-yr scale at Santiago Vila Airport during the period 1960-65 (Fig. 4) can be interpreted in different ways: On the one hand, the significant spectrum starts in the very beginning of the time series within the cone of influence (Fig. 4b), so the edge effects might be relevant (Torrence and Compo 1998; Adamowski 2008). On the other hand, there are no moderate-strong phases of ENSO until late 1964-except for two single months in 1962 (January and April; Fig. 4c). The 1966-68 wavelet spectra therefore are interpreted as an effect of a rather long period of missing data in that time (Fig. 4a). Apart from the two mentioned spectra there are no significant spectra on longer scales identified for Santiago Vila Airport. Hence, there are no significant wavelet spectra on a scale that can be interpreted as caused by ENSO, 
albeit in the lower altitudes of the central Andes dry season's rainfall is reported to be related to ENSO via the Oceanic Niño index (ONI) (Ramirez and Jaramillo 2009).

The two Highland weather stations Australia and Lagunitas have nothing in common with regard to their wavelet spectra. While the data from Australia (Fig. 5b) indicate an omnipresent significant spectrum at an annual scale, Lagunitas (Fig. 6b) is characterized by only a few significant spectra. There is a remarkable wavelet spectrum at the 8-yr scale starting in 2005 and lasting until the end of the time series from Lagunitas station. It coincides with the onset of a phase of pronounced rainfall and an increased variance of rainfall (Fig. 6a). This time period is marked by weak to moderate El Niño phases and two strong La Niña events (2007-08 and 2010-11). This cyclicity on larger time scales ( $>2$ years) starting in the early 2000s also appears in the wavelet spectra of Guasca and El Corazon located in the Altiplano, but it is less pronounced.

At the weather station Guasca, the wavelet spectrum is significant on a 4-yr scale in the period of 2005-13. However, during this time period too many missing values of the monthly rainfall data are missing in order to draw valid conclusions, but in 2010-12 at least the variance of rainfalls increased significantly (Fig. 9a). At El Corazon (Fig. 7b) this pattern differs. In 2010, just within a strong La Niña phase (Hoyos et al. 2013), the wavelet spectra turn significant on a 3-yr scale until 2013. The monthly rainfall values rise with increased variance (Fig. 7a) during and sometime after the strong La Niña phase (approximately 2013). At El Corazon, another significant wavelet spectrum on a time scale most likely related to ENSO can be distinguished covering vast parts of the 1990s. This spectrum is significant on a 4-yr scale in the period of time 1993-2001. This coincides with the onset of a phase of pronounced rainfall after a phase of relative minima in the early 1990s (Fig. 7a). Nonetheless, it needs to be mentioned, that in 1991 and 1992 missing values in the time series of monthly rainfall data might distort these results. At least, in the second half of 1992 and onward until 1995, where the raw monthly rainfall data are complete, the time series reveals relative minima. Within this phase, the 1997/98 El Niño event is marked by a sharp decline of variance of monthly rainfall values. Since in the Sabana de Bogotá El Niño events are associated with rainfall amounts below average (Pabón and Torres 2007) this is interpreted as a direct response of the local weather conditions to ENSO.

At the station Observatorio Meteorológico Nacional, the wavelet spectra are significant on a 3-yr scale from 1977 to 1982 (Fig. 8b). For that period, no strong or moderate phase of ENSO has been recorded (Fig. 8c). Additionally, here the late 1970s and early 1980s are marked by a cumulation of missing values of monthly rainfall data (Fig. 8a). Thus, also these spectra must be considered faulty and as there are no such significant spectra anywhere else in the rainfall data of this station, it appears unlikely to be affected by ENSO directly.

Generally, the results on ENSO-scale cycles within the monthly rainfall data from six weather stations in and around Bogotá do not appear clear and conclusive, but overall the impact of ENSO on Andean precipitation appears to be less distinct than observed for river discharge (Poveda et al. 2001a).
ENSO events propagate wavelike from the Pacific coast through the Andes and become weaker to the east (Poveda et al. 2011). Correspondingly, it is possible that only few ENSO events' signals reach the Cordillera Oriental, as ENSO events do not necessarily impact all parts of the Andes (Compagnucci 2000). In addition, ENSO impacts can be weaker than intraannual seasonality due to the influence of local orographic factors, the intensity of hurricanes and tropical cyclones over the Intra-Americas Seas (IAS), cold fronts, trade winds, and the southward shift of the ITZC (Pinilla Herrera and Pinzón Correa 2016).

\section{2) SEMESTRAL AND ANNUAL CYCLES}

Several of the tested weather stations have significant wavelet spectra on a semestral time scale. Especially in the Lowlands (Santiago Vila Airport) and on the Altiplano at El Corazon station and Observatorio Meteorológico Nacional the 0.5 -yr cycle is stands out, which agrees well with the bimodal pattern of rainfall (Fig. 3) as described by Hoyos et al. (2005) and Velandia (2016).

The annual rainfall pattern of Australia reveals that the source of moisture in boreal summer months must be a different one than for the other stations. The significant spectra on an annual time scale covering the whole time series (with a minimum of missing values) underlines this impressively (Fig. 5b). Vizy and Cook (2007) report connections between the rainfalls in the Amazon region and in the high Andes. For the northernmost part of the Altiplano, Saylor et al. (2009) list possible sources of precipitation, but further investigation is needed to confirm this for the northern part of the Cordillera Oriental branch.

At Lagunitas station the semestral cycle in the period 201012 is superimposed by an annual cycle. These cycles coincide with a phase of pronounced variance of rainfalls between 2010 and 2013, while the significant wavelet spectra on a semestral scale in 2005-07 can only be related to a peak event in 2005 (Fig. 6a). While significant semestral or annual spectra are scarce at Lagunitas, it is presumed that this station's rainfalls are subject to different influences than the other stations.

Guasca offers only some phases with significant power spectra on a 0.5 -yr scale. Additionally, some phases on 0.25 and 1-yr spectra occur. This result can be interpreted in two different ways: (i) Wavelet transformation is susceptible to false fluctuations (Foster 1996). The high amount of missing values $(7.74 \%)$ with a rather even distribution in the time series of monthly rainfall data is interfering the CWT and leads to a faulty response. (ii) The area is characterized by features of semestral- and annual-scale rainfall cycles. The present rainfall regime is that of the Altiplano (semestral), but with interference of the easternmost mountain chain and its corresponding rainfall. Hence, it is interpreted that Guasca is located in a transitional location where characteristics of precipitation might depend on the strength of atmospheric conditions.

\section{d. Relationship of monthly precipitation and multivariate ENSO index}

The Spearman rank correlation coefficients of the monthly rainfall data and the MEI values vary between -0.028 and 
-0.242 (Figs. 4d-9d). This indicates the lack of a direct relation between MEI and rainfalls, although nonparametric measures proved its capabilities in detecting ENSO-related phenomena in all phases of ENSO (Singhrattna et al. 2005). The 12-month filtered precipitation values and MEI also do not show coherent and conclusive correlations. One the one hand, a 12-month vector is highly susceptible to missing values. This, for example, is documented in the data of Observatorio Meteorológico Nacional station (Fig. 8c) when in 1978 a large gap of missing data occurs and the $\rho$ values increase as a consequence. Since $n<10$ is considered of poor normal approximation (Kirk 2007), the $\rho$ values in the surroundings of missing values in the monthly rainfall data have to be interpreted with care. On the other hand, $\rho$ values appear inconclusive and do not show any relation to MEI values even in periods without missing values.

The authors are aware that it is not common to analyze a single month and its relation to ENSO. Alternatively, to overcome the problem of missing data, seasonalized data could have been used, which was applied in various studies (e.g., Espinoza Villar et al. 2008; Pinilla Herrera and Pinzón Correa 2016), or classified precipitation values could have been used, as De Silva and Hornberger (2019) demonstrated.

The success of correlation analyses strongly depends on the parameters under study and on the regional context. Apart from the regional context basically two questions arise: (i) Which index should be used to correlate rainfall data? There are plenty of indices to delineate ENSO, such as Southern Oscillation index (SOI), SST, ONI, PDO, dipole mode index (DMI; https://stateoftheocean.osmc.noaa.gov/sur/ind/dmi.php), and Niño-1-4, but the MEI is considered to be superior over single variable indices, since single variable indices are more prone to non-ENSO-related variability (Kiem and Franks 2001) or-in contradiction-MEI appears to be more sensible in detecting ENSO events in comparison to univariate indices (Hanley et al. 2003). This is possibly caused by the superior capabilities in detecting correlations in a long-term primarily stochastic-driven regime (Southern Oscillation) in phases beyond the order of one month (Ortiz-Tánchez et al. 2002).

Moreover, by using multivariate data the MEI can vary with the seasonal cycle (Mazzarella et al. 2013) and the utilization of multiple variables makes it less susceptible to possible instrumentation errors. And because ENSO is a phenomenon that stands out due to complexity, nonlinearity, and irregularity the MEI concept of reducing complexity by principal component analysis is a superior choice in ENSO monitoring (Wolter and Timlin 1993, 2011; Webb 2017).

(ii) If correlation analyses of rainfall data and such climate oscillations as ENSO are applied using time lags- how many lags are appropriate? There are numerous studies pointing out an ENSO impact on ecohydrological properties; for example, Ávila et al. (2019) show that extreme rainfall can be associated with ENSO in the Cauca valley, Restrepo and Kjerfve (2000) show that river runoff data and SOI in northern Colombia are in phase, Ramirez and Jaramillo (2009) found a correlation between the ONI and unlagged precipitation data in the central Andes, and Puertas Orozco and Carvajal Escobar (2008) indicate lags of zero or close to zero for rainfall and MEI to correlate successfully. On the other hand, there are just as many studies that found only weak or neglectable correlations between ENSO and environmental processes or no correlation at all (Chiew et al. 1998; Compagnucci 2000; Aguilar et al. 2005; Arango et al. 2015).

In this study various lags and filters have been tested to apply correlation analyses, but none of it showed reasonable results (not presented here). In consequence, the 12-month filtered rainfall values were chosen for correlation analyses (Figs. 4c-9c). The inconclusive correlation suggests that between monthly rainfall sums and positive or negative ENSO events no direct relation exists. This finding also supports the conclusions drawn from the CWT analyses. Additionally, this lack of correlation between ENSO and monthly rainfall in the wider Andean Cordillera Oriental is supported by the findings of Poveda and Mesa (1997) who point out that river discharge and SOI correlate less well in the eastern Andean range than close to the Pacific Ocean.

\section{Conclusions}

We suggest that the rainfall regime in the Rio Bogotá watershed is controlled by mesoscale topoclimates that are determined by the course of the ITCZ through the year. This is supported by (i) the mostly bimodal pattern in the precipitation data, (ii) the significance of the 0.5 -yr cycles in the CWT, and (iii) the poor correlation of monthly rainfall data at the different stations among each other (Table 3).

Statistical analysis implies that the monthly rainfall sums of the weather stations located on the Altiplano are quite comparable. Observatorio Meteorológico Nacional station shows increased values compared to those of the other stations, which is considered to result from its location in the middle of an urbanized area. In contrast, the monthly rainfall sums at the Highland stations differ-in parts-strongly, which is interpreted as an expression of increased topoclimatical impact. Hence, here the same mechanisms and forcings are active as the ones in the Altiplano, but with a more direct effect. Time series of monthly rainfall data at Australia station is different from those of the other stations in multiple ways (unimodal, 1-yr cycle). This is related either to a certain topographical setting or to additional precipitable moisture coming in from the Amazon basin in the low rainy season of the boreal summer. A valid assessment cannot be provided by this study.

The bimodal character of precipitation can be confirmed by CWT analyses for at least four stations. Significant wavelet spectra of monthly rainfall data on time scales that could be related to ENSO phenomena do not occur. For the stations El Corazon, Guasca, and Lagunitas some significant spectra can be distinguished, but overall, it seems implausible that within such a relatively small area the continental-scale ENSO phenomenon indicates both significant impact and no impact on different weather stations simultaneously. A distinct statistical correlation between monthly rainfall data and ENSO phases cannot be confirmed for the Sabana de Bogotá either for the complete time series or for lagged subsets. The existing positive or negative correlating values do not show conclusive results.

There are many continental-scaled studies covering ENSO and its relationship to ecohydrological properties, but only a 
few regional studies exist. With the study at hand, we want to contribute to regional studies on ENSO and rainfall variability. An improved understanding of regional rainfall variability and its sources is also conducive to a better understanding of different parts of the hydrological cycle in Andean environments as well as to their assessment, management, and forecasting. We assume that this will be one of the major challenges in the metropolitan area of Bogotá during the decades to come.

Furthermore, this study provides information to local institutions and local decision-makers to improve resource management plans and to mitigate the impact of a changing climate, especially in the context of (endangered) mountain forest ecosystems and alpine biomes in one of Earth's most important biodiversity hot spots.

Acknowledgments. This research was supported by the Federal Ministry of Education and Research of Germany (ColBioDiv—01DN17006 and Pilot project—01DN13030).

\section{REFERENCES}

Abril-Salcedo, D. S., L. F. Melo-Velandia, and D. Parra-Amado, 2016: Impactos de los fenómenos climáticos sobre el precio de los alimentos en Colombia. Ensayos sobre Política Econ., 34, 146-158, https://doi.org/10.1016/J.ESPE.2016.03.003.

Abud, M., and Coauthors, 2017: Biodiversity 2016: Status and trends of Colombian continental biodiversity. Instituto de Investigación de Recursos Biológicos Alexander von Humboldt, 50 pp., http://repository.humboldt.org.co/handle/20.500.11761/ 32963.

Aceituno, P., M. R. Prieto, M. E. Solari, A. Martínez, G. Poveda, and M. Falvey, 2009: The 1877-1878 El Niño episode: Associated impacts in South America. Climatic Change, 92, 389-416, https://doi.org/10.1007/s10584-008-9470-5.

Adamowski, J. F., 2008: River flow forecasting using wavelet and cross-wavelet transform models. Hydrol. Processes, 22, 48774891, https://doi.org/10.1002/hyp.7107.

Aguilar, E., and Coauthors, 2005: Changes in precipitation and temperature extremes in Central America and northern South America, 1961-2003. J. Geophys. Res., 110, D23107, https://doi.org/10.1029/ 2005JD006119.

Alexander, M. A., I. Bladé, M. Newman, J. R. Lanzante, N.-C. Lau, and J. D. Scott, 2002: The atmospheric bridge: The influence of ENSO teleconnections on air-sea interaction over the global oceans. J. Climate, 15, 2205-2231, https://doi.org/10.1175/15200442(2002)015\%3C2205:tabtio\%3E2.0.co;2.

Allen, C. D., and Coauthors, 2010: A global overview of drought and heat-induced tree mortality reveals emerging climate change risks for forests. For. Ecol. Manage., 259, 660-684, https://doi.org/10.1016/j.foreco.2009.09.001.

Andriessen, P. A. M., K. F. Helmens, H. Hooghiemstra, P. A. Riezebos, and T. Van der Hammen, 1993: Absolute chronology of the Pliocene-Quaternary sediment sequence of the Bogota area, Colombia. Quat. Sci. Rev., 12, 483-501, https:// doi.org/10.1016/0277-3791(93)90066-U.

Anselm, N., G. Brokamp, and B. Schütt, 2018: Assessment of land cover change in peri-urban high Andean environments south of Bogotá, Colombia. Land, 7, 75, https://doi.org/10.3390/ LAND7020075.

Antonio-Fragala, F., and N. Obregón-Neira, 2011: Estimación de la recarga media anual en los acuíferos de la sabana de Bogotá. Ing. Univ. Bogotá, 15, 145-169.
Arango, C., J. Dorado, D. Guzmán, and J. Ruiz, 2015: Climatología trimestral de Colombia. IDEAM Tech. Rep., 19 pp., http:// www.ideam.gov.co/documents/21021/21789/Climatolog\%C3\% $\mathrm{ADa}+$ Trimestral + para + Colombia $+\% 28 \mathrm{Ruiz} \% 2 \mathrm{C}+$ Guzman \%2C +Arango +y+Dorado\%29.pdf/c2825963-c373-449a-a7cb$8480874478 \mathrm{~d} 9$.

Armenteras, D., F. Gast, and H. Villareal, 2003: Andean forest fragmentation and the representativeness of protected natural areas in the eastern Andes, Colombia. Biol. Conserv., 113, 245-256, https://doi.org/10.1016/S0006-3207(02)00359-2.

_, N. Rodríguez, J. Retana, and M. Morales, 2011: Understanding deforestation in montane and lowland forests of the Colombian Andes. Reg. Environ. Change, 11, 693-705, https://doi.org/ 10.1007/s10113-010-0200-y.

Ávila, A., F. C. Guerrero, Y. C. Escobar, and F. Justino, 2019: Recent precipitation trends and floods in the Colombian Andes. Water, 11, 379, https://doi.org/10.3390/w11020379.

Balthazar, V., V. Vanacker, A. Molina, and E. F. Lambin, 2015: Impacts of forest cover change on ecosystem services in high Andean mountains. Ecol. Indic., 48, 63-75, https://doi.org/ 10.1016/j.ecolind.2014.07.043.

Baylis, M., P. S. Mellor, and R. Meiswinkel, 1999: Horse sickness and ENSO in South Africa. Nature, 397, 574, https://doi.org/ $10.1038 / 17512$.

Bedoya-Soto, J. M., G. Poveda, K. E. Trenberth, and J. J. VélezUpegui, 2018: Interannual hydroclimatic variability and the 2009-2011 extreme ENSO phases in Colombia: From Andean glaciers to Caribbean lowlands. Theor. Appl. Climatol., 135, 1531-1544, https://doi.org/10.1007/S00704-018-2452-2.

Bernal, G., M. Rosero, M. Cadena, J. Montealegre, and F. Sanabria, 2007: Estudio de la Caracterización Climática de Bogotá y cuenca alta del Río Tunjuelo. IDEAM, 122 pp.

Bookhagen, B., and M. R. Strecker, 2008: Orographic barriers, high-resolution TRMM rainfall, and relief variations along the eastern Andes. Geophys. Res. Lett., 35, L06403, https:// doi.org/10.1029/2007GL032011.

Borys, R. D., D. H. Lowenthal, and D. L. Mitchell, 2000: The relationships among cloud microphysics, chemistry, and precipitation rate in cold mountain clouds. Atmos. Environ., 34, 2593-2602, https://doi.org/10.1016/S1352-2310(99)00492-6.

Brando, J., and R. J. Santos, 2015: La Niña y los Niños: Effects of an unexpected winter on early life human capital and family responses. Universidad de los Ande-CEDE, 60 pp., http:// economia.uniandes.edu.co/publicaciones/dcede2015-25.pdf.

Briner, S., C. Elkin, R. Huber, and A. Grêt-Regamey, 2012: Assessing the impacts of economic and climate changes on land-use in mountain regions: A spatial dynamic modeling approach. Agric. Ecosyst. Environ., 149, 50-63, https://doi.org/ 10.1016/j.agee.2011.12.011.

Bulmer, M. G., 1979: Principles of Statistics. Dover Books on Mathematics, Courier Corporation, 252 pp.

Bunn, A., and Coauthors, 2018: dplR: Dendrochronology Program Library in $\mathrm{R}$, version 1.7.1. R package, https://CRAN.Rproject.org/package $=\mathrm{d}$ plR.

Buytaert, W., and T. Breuer, 2013: Water resources in South America: sources and supply, pollutants and perspectives. IAHS Publ., 359-, 106-113.

_ B. Be Bièvre, G. Wyseure, and J. Deckers, 2004: The use of the linear reservoir concept to quantify the impact of changes in land use on the hydrology of catchments in the Andes. Hydrol. Earth Syst. Sci., 8, 108-114, https://doi.org/10.5194/hess-8-108-2004.

_- R. Celleri, P. Willems, B. D. Bièvre, and G. Wyseure, 2006a: Spatial and temporal rainfall variability in mountainous areas: 
A case study from the south Ecuadorian Andes. J. Hydrol., 329, 413-421, https://doi.org/10.1016/j.jhydrol.2006.02.031.

_ , R. Célleri, B. De Bièvre, F. Cisneros, G. Wyseure, J. Deckers, and R. Hofstede, 2006b: Human impact on the hydrology of the Andean páramos. Earth-Sci. Rev., 79, 53-72, https:// doi.org/10.1016/j.earscirev.2006.06.002.

—, V. Iñiguez, R. Celleri, B. D. Bièvre, G. Wyseure, and J. Deckers, 2006c: Analysis of the water balance of small páramo catchments in south Ecuador. Environmental Role of Wetlands in Headwaters, J. Krecek and M. Haigh, Eds., NATO Science Series: IV: Earth and Environmental Sciences, Vol. 63, Springer, 271-281.

Cadena, M. C., A. Devis-Morales, J. D. Pabón I. Málikov, J. A. Reyna-Moreno, and J. R. Ortiz, 2006: Relationship between the 1997/98 El Niño and 1999/2001 La Niña events and oil palm tree production in Tumaco, southwestern Colombia. $A d v$. Geosci., 6, 195-199, https://doi.org/10.5194/adgeo-6-195-2006.

Capotondi, A., and Coauthors, 2015: Understanding ENSO diversity. Bull. Amer. Meteor. Soc., 96, 921-938, https://doi.org/ 10.1175/BAMS-D-13-00117.1.

Corporación Autónoma Regional de Cundinamarca, 2017: Evaluación Regional del Agua-ERA Cuenca Alta río Bogotá. Imprenta Nacional de Colombia, 308 pp., https://sie.car.gov.co/bitstream/ handle/20.500.11786/35777/Evaluaci\%C3\%B3n\%20regional\% $20 \mathrm{del} \% 20$ agua.pdf? sequence $=1 \&$ isAllowed $=y$.

Cárdenas, M. F., C. Tobón, and W. Buytaert, 2017: Contribution of occult precipitation to the water balance of páramo ecosystems in the Colombian Andes. Hydrol. Processes, 31, 44404449, https://doi.org/10.1002/hyp.11374.

Carmona, A. M., and G. Poveda, 2014: Detection of long-term trends in monthly hydro-climatic series of Colombia through empirical mode decomposition. Climatic Change, 123, 301313, https://doi.org/10.1007/s10584-013-1046-3.

Celleri, R., P. Willems, W. Buytaert, and J. Feyen, 2007: Spacetime rainfall variability in the Paute basin, Ecuadorian Andes. Hydrol. Processes, 21, 3316-3327, https://doi.org/10.1002/hyp.6575.

Chazdon, R. L., A. R. Brenes, and B. V. Alvarado, 2005: Effects of climate and stand age on annual tree dynamics in tropical second-growth rain forests. Ecology, 86, 1808-1815, https:// doi.org/10.1890/04-0572.

Chiew, F. H. S., T. C. Piechota, J. A. Dracup, and T. A. McMahon, 1998: El Niño/Southern Oscillation and Australian rainfall, streamflow and drought: Links and potential for forecasting. J. Hydrol., 204, 138-149, https://doi.org/10.1016/S0022-1694(97) 00121-2.

Compagnucci, R. H., 2000: Impact of ENSO events on the hydrological system of the Cordillera de los Andes during the last 450 years. Southern Hemisphere Paleo- and Neoclimates, Springer, 175-185, https://link.springer.com/chapter/10.1007/ 978-3-642-59694-0_12.

Condit, R., S. P. Hubbell, and R. B. Foster, 1995: Mortality rates of 205 neotropical tree and shrub species and the impact of a severe drought. Ecol. Monogr., 65, 419-439, https://doi.org/ $10.2307 / 2963497$.

Córdoba-Machado, S., R. Palomino-Lemus, S. R. Gámiz-Fortis, Y. Castro-Díez, and M. J. Esteban-Parra, 2015: Assessing the impact of El Niño Modoki on seasonal precipitation in Colombia. Global Planet. Change, 124, 41-61, https://doi.org/ 10.1016/j.gloplacha.2014.11.003.

Dai, A., and K. E. Trenberth, 2002: Estimates of freshwater discharge from continents: Latitudinal and seasonal variations. J. Hydrometeor., 3, 660-687, https://doi.org/10.1175/ 1525-7541(2002)003<0660:EOFDFC >2.0.CO;2.
Danielson, J. J., and D. B. Dahl, 2011: Global Multi-resolution Terrain Elevation Data 2010 (GMTED2010). USGS Open File Rep. 2011-1073, 34 pp., https://pubs.usgs.gov/of/2011/ 1073/pdf/of2011-1073.pdf.

Daubechies, I., 1990: The wavelet transform, time-frequency localization and signal analysis. IEEE Trans. Inf. Theory, 36, 961-1005, https://doi.org/10.1109/18.57199.

Departamento Administrativo Nacional de Estadística, 2012: Atlas estadístico de Colombia. DANE, https://geoportal.dane.gov. co/servicios/atlas-estadistico/.

De Silva, T., and G. M. Hornberger, 2019: Identifying El NiñoSouthern Oscillation influences on rainfall with classification models: Implications for water resource management of Sri Lanka. Hydrol. Earth Syst. Sci., 23, 1905-1929, https://doi.org/ 10.5194/hess-23-1905-2019.

Dixon, P. G., and T. L. Mote, 2003: Patterns and causes of Atlanta's urban heat island-initiated precipitation. J. Appl. Meteor., 42, 1273-1284, https://doi.org/10.1175/1520-0450(2003)042<1273: PACOAU $>2.0 . \mathrm{CO} ; 2$.

Douglas, A. V., D. R. Cayan, and J. Namias, 1982: Large-scale changes in North Pacific and North American weather patterns in recent decades. Mon. Wea. Rev., 110, 1851-1862, https://doi.org/10.1175/1520-0493(1982)110\%3C1851:LSCINP\% 3E2.0.CO;2.

Espinoza Villar, J. C., and Coauthors, 2008: Spatio-temporal rainfall variability in the Amazon basin countries (Brazil, Peru, Bolivia, Colombia, and Ecuador). Int. J. Climatol., 29, 1574-1594, https://doi.org/10.1002/joc.1791.

Falkenmark, M., and Z. Mikulski, 1994: The key role of water in the landscape system. GeoJournal, 33, 355-363, https://doi.org/ 10.1007/BF00806417.

Foster, G., 1996: Wavelets for period analysis of unevenly sampled time series. Astron. J., 112, 1709, https://doi.org/10.1086/118137.

Gallego, D., R. García-Herrera, F. P. Gómez-Delgado, P. OrdoñezPerez, and P. Ribera, 2018: Tracking the Choco jet since the 19th century by using historical wind direction measurements. Earth Syst. Dyn. Discuss., 1-23, https://doi.org/10.5194/esd-2018-54.

García, N. O., 1994: South American climatology. Quat. Int., 21, 7-27, https://doi.org/10.1016/1040-6182(94)90018-3.

Giralt, S., and Coauthors, 2007: The history of the El Niño-Southern Oscillation according to lacustrine and marine sediments. Contrib. Sci., 3, 343-353, https://doi.org/10.2436/20.7010.01.12.

Graham, N. E., and W. B. White, 1988: The El Niño cycle: A natural oscillator of the Pacific Ocean-atmosphere system. Science, 240, 1293-1302, https://doi.org/10.1126/science.240.4857.1293.

Gross, J., and U. Ligges, 2015: nortest: Tests for normality, version 1.0-4. $\mathrm{R}$ package, https://CRAN.R-project.org/package $=$ nortest.

Grubb, P. J., 1977: The maintenance of species-richness in plant communities: The importance of the regeneration Niche. Biol. Rev. Camb. Philos. Soc., 52, 107-145, https://doi.org/10.1111/ j.1469-185X.1977.tb01347.x.

Gu, D., and S. G. H. Philander, 1995: Secular changes of annual and interannual variability in the tropics during the past century. J. Climate, 8, 864-876, https://doi.org/10.1175/1520-0442(1995) 008<0864:SCOAAI $>2.0 . \mathrm{CO} ; 2$.

Guhl Nimtz, E., 1982: Páramos Circundantes de la Sábana de Bogotá. 2nd ed. Jardín Botánico, 127 pp.

Gutiérrez, F., and J. A. Dracup, 2001: An analysis of the feasibility of long-range streamflow forecasting for Colombia using El Niño-Southern Oscillation indicators. J. Hydrol., 246, 181196, https://doi.org/10.1016/S0022-1694(01)00373-0.

Guzmán, D., J. Ruiz, and M. Cadena, 2014: Regionalización de Colombia según la estacionalidad de la precipitación 
media mensual, a través de Análisis de Componentes Principales. IDEAM Tech. Rep., 40 pp., https://institucional.ideam.gov. co/descargas $? \mathrm{com}=$ institucional $\&$ name $=$ pubFile $15513 \&$ downloadname $=$ Regionalizacion.

Hadjileontiadis, L. J., 2018: Continuous wavelet transform and higher-order spectrum: Combinatory potentialities in breath sound analysis and electroencephalogram-based pain characterization. Philos. Trans. Roy. Soc., 376A, 2017 0249, https:// doi.org/10.1098/rsta.2017.0249.

Hanley, D. E., M. A. Bourassa, J. J. O'Brien, S. R. Smith, and E. R. Spade, 2003: A quantitative evaluation of ENSO indices. J. Climate, 16, 1249-1258, https://doi.org/10.1175/1520-0442(2003) 16<1249:AQEOEI >2.0.CO;2.

Hastenrath, S., 2002: The intertropical convergence zone of the eastern Pacific revisited. Int. J. Climatol., 22, 347-356, https:// doi.org/10.1002/joc.739.

Helmens, K. F., and T. van der Hammen, 1994: The Pliocene and Quaternary of the high plain of Bogotá (Colombia): A history of tectonic uplift, basin development and climatic change. Quat. Int., 21, 41-61, https://doi.org/10.1016/1040-6182(94)90020-5.

Hoorn, C., J. Guerrero, G. A. Sarmiento, and M. A. Lorente, 1995: Andean tectonics as a cause for changing drainage patterns in Miocene northern South America. Geology, 23, 237-240, https://doi.org/10.1130/0091-7613(1995)023<0237:ATAACF> 2.3.CO;2.

Hoyos, I., J. Cañón-Barriga, T. Arenas-Suárez, F. Dominguez, and B. A. Rodríguez, 2018: Variability of regional atmospheric moisture over northern South America: Patterns and underlying phenomena. Climate Dyn., 53, 893-911, https://doi.org/ 10.1007/S00382-018-4172-9.

Hoyos, N., P. R. Waylen, and A. Jaramillo, 2005: Seasonal and spatial patterns of erosivity in a tropical watershed of the Colombian Andes. J. Hydrol., 314, 177-191, https://doi.org/ 10.1016/j.jhydrol.2005.03.014.

— J. Escobar, J. C. Restrepo, A. M. Arango, and J. C. Ortiz, 2013: Impact of the 2010-2011 La Niña phenomenon in Colombia, South America: The human toll of an extreme weather event. Appl. Geogr., 39, 16-25, https://doi.org/10.1016/ j.apgeog.2012.11.018.

Huff, F. A., and S. A. Changnon, 1973: Precipitation modification by major urban areas. Bull. Amer. Meteor. Soc., 54, 1220-1233, https://doi.org/10.1175/1520-0477(1973)054\%3C1220:PMBMUA\% 3E2.0.CO;2.

Hurrell, J. W., Y. Kushnir, and M. Visbeck, 2001: The North Atlantic Oscillation. Science, 291, 603-605, https://doi.org/ 10.1126/science.1058761.

IDEAM, 2017: Daily rainfall values from Australia Station [21205230]. Instituto de Hidrologia, Meteorologia y Estudios Ambientales, accessed 12 December 2016, http://institucional.ideam.gov.co/jsp/ index.jsf.

Iizumi, T., J.-J. Luo, A. J. Challinor, G. Sakurai, M. Yokozawa, H. Sakuma, M. E. Brown, and T. Yamagata, 2014: Impacts of El Niño Southern Oscillation on the global yields of major crops. Nat. Commun., 5, 3712, https://doi.org/10.1038/ncomms4712.

Jaramillo-Robledo, A., and B. Chaves-Córdoba, 2000: Distribución de la precipitación en Colombia analizada mediante conglomeración estadística. Cenicafé, 51, 102-113.

Kestin, T. S., D. J. Karoly, J.-I. Yano, and N. A. Rayner, 1998: Time-frequency variability of ENSO and stochastic simulations. J. Climate, 11, 2258-2272, https://doi.org/10.1175/15200442(1998)011<2258:TFVOEA > 2.0.CO;2.

Kiem, A. S., and S. W. Franks, 2001: On the identification of ENSO-induced rainfall and runoff variability: A comparison of methods and indices. Hydrol. Sci. J., 46, 715-727, https:// doi.org/10.1080/02626660109492866.

Kirk, R. E., 2007: Statistics: An Introduction. 5th ed. Cengage Learning, $627 \mathrm{pp}$.

Köppen, W., 1923: Die Klimate der Erde: Grundriss der Klimakunde. Walter de Gruyter, 369 pp., https://doi.org/10.1515/9783111491530.

Kottek, M., J. Grieser, C. Beck, B. Rudolf, and F. Rubel, 2006: World map of the Köppen-Geiger climate classification updated. Meteor. Z., 15, 259-263, https://doi.org/10.1127/09412948/2006/0130.

Kousky, V. E., and M. T. Kagano, 1981: A climatological study of the tropospheric circulation over the Amazon region. Acta Amazonica, 11, 743-758, https://doi.org/10.1590/180943921981114743.

Kwiatkowski, D., P. C. B. Phillips, P. Schmidt, and Y. Shin, 1992: Testing the null hypothesis of stationarity against the alternative of a unit root: How sure are we that economic time series have a unit root? J. Econom., 54, 159-178, https:// doi.org/10.1016/0304-4076(92)90104-Y.

Latrubesse, E. M., J. C. Stevaux, and R. Sinha, 2005: Tropical rivers. Geomorphology, 70, 187-206, https://doi.org/10.1016/ j.geomorph.2005.02.005.

Liu, Z., and H. Yang, 2003: Extratropical control of tropical climate, the atmospheric bridge and oceanic tunnel. Geophys. Res. Lett., 30, 1230, https://doi.org/10.1029/2002GL016492.

- , and M. Alexander, 2007: Atmospheric bridge, oceanic tunnel, and global climatic teleconnections. Rev. Geophys., 45, RG2005, https://doi.org/10.1029/2005RG000172.

Lopez, O. R., and T. A. Kursar, 2007: Interannual variation in rainfall, drought stress and seedling mortality may mediate monodominance in tropical flooded forests. Oecologia, 154, 35-43, https://doi.org/10.1007/s00442-007-0821-0.

Lutz, D. A., R. L. Powell, and M. R. Silman, 2013: Four decades of Andean timberline migration and implications for biodiversity loss with climate change. PLOS ONE, 8, e74496, https:// doi.org/10.1371/journal.pone.0074496.

Makarieva, A. M., and V. G. Gorshkov, 2007: Biotic pump of atmospheric moisture as driver of the hydrological cycle on land. Hydrol. Earth Syst. Sci., 11, 1013-1033, https://doi.org/10.5194/ hess-11-1013-2007.

Mantilla, G., H. Oliveros, and A. G. Barnston, 2009: The role of ENSO in understanding changes in Colombia's annual malaria burden by region, 1960-2006. Malaria J., 8, 6, https:// doi.org/10.1186/1475-2875-8-6.

Marin, S., and J. A. Ramírez, 2006: The response of precipitation and surface hydrology to tropical macro-climate forcing in Colombia. Hydrol. Processes, 20, 3759-3789, https://doi.org/ 10.1002/hyp.6387.

Martínez, I., L. Keigwin, T. T. Barrows, Y. Yokoyama, and J. Southon, 2003: La Niña-like conditions in the eastern equatorial Pacific and a stronger Choco jet in the northern Andes during the last glaciation. Paleoceanography, 18, 1033, https://doi.org/10.1029/2002PA000877.

Mazzarella, A., A. Giuliacci, and N. Scafetta, 2013: Quantifying the multivariate ENSO index (MEI) coupling to $\mathrm{CO}_{2}$ concentration and to the length of day variations. Theor. Appl. Climatol., 111, 601-607, https://doi.org/10.1007/s00704-012-0696-9.

Mertins, A., 2001: Wavelet transform. Signal Analysis, WileyBlackwell, 210-264, https://onlinelibrary.wiley.com/doi/abs/ 10.1002/0470841834.ch8.

Meyers, S. D., B. G. Kelly, and J. J. O'Brien, 1993: An introduction to wavelet analysis in oceanography and meteorology: With application to the dispersion of Yanai waves. Mon. Wea. Rev., 121, 
2858-2866, https://doi.org/10.1175/1520-0493(1993)121<2858: AITWAI $>2.0 . \mathrm{CO} ; 2$.

Miralles, D. G., and Coauthors, 2014: El Niño-La Niña cycle and recent trends in continental evaporation. Nat. Climate Change, 4, 122-126, https://doi.org/10.1038/nclimate2068.

Montgomery, D. R., G. Balco, and S. D. Willett, 2001: Climate, tectonics, and the morphology of the Andes. Geology, 29, 579-582, https://doi.org/10.1130/0091-7613(2001)029<0579: CTATMO $>2.0 . \mathrm{CO} ; 2$.

Montoya Arenas, D. M., and G. A. Reyes Torres, 2005: Geología de la Sabana de Bogotá. Ingeominas, 104 pp.

Nobre, C. A., P. J. Sellers, and J. Shukla, 1991: Amazonian deforestation and regional climate change. J. Climate, $\mathbf{4}$, 957-988, https://doi.org/10.1175/1520-0442(1991)004\%3C0957: ADARCC\%3E2.0.CO;2.

Ortiz-Tánchez, E., W. Ebeling, and K. Lanius, 2002: MEI, SOI and mid-range correlations in the onset of El Niño-Southern Oscillation. Physica, 310, 509-520, https://doi.org/10.1016/ S0378-4371(02)00812-9.

Pabón, J. D., and G. Torres, 2007: Impacto socioeconómico de los fenómenos El Niño y La Niña en la Sabana de Bogotá durante el siglo XX. Cuad. Geogr.: Rev. Colombiana Geogr., 16, 81-94, https://revistas.unal.edu.co/index.php/rcg/article/ view/10161.

Philander, S. G. H., 1983: El Niño Southern Oscillation phenomena. Nature, 302, 295-301, https://doi.org/10.1038/302295a0.

Pineda, L. E., and P. Willems, 2018: Rainfall extremes, weather and climate drivers in complex terrain: A data-driven approach based on signal enhancement methods and EV modeling. J. Hydrol., 563, 283-302, https://doi.org/10.1016/j.jhydrol.2018.05.062.

Pinilla Herrera, M. C., and C. A. Pinzón Correa, 2016: An assessment of El Niño and La Niña impacts focused on monthly and seasonal rainfall and extreme dry/precipitation events in mountain regions of Colombia and México. Adv. Geosci., 42, 23-33, https://doi.org/10.5194/adgeo-42-23-2016.

Postel, S. L., 2000: Entering an era of water scarcity: The challenges ahead. Ecol. Appl., 10, 941-948, https://doi.org/10.1890/10510761(2000)010[0941:EAEOWS]2.0.CO;2.

Poveda, G., 2004: La hidroclimatología de Colombia: Una síntesis desde la escala inter-decadal hasta la escala diurna. Rev. Acad. Colomb. Cienc. Exactas Fis. Nat., 28, 201-222.

— cesses in tropical South America and large-scale oceanatmospheric phenomena. J. Climate, 10, 2690-2702, https:// doi.org/10.1175/1520-0442(1997)010<2690:FBHPIT>2.0.CO;2.

, and - 2000: On the existence of Lloró (the rainiest locality on Earth): Enhanced ocean-land-atmosphere interaction by a low-level jet. Geophys. Res. Lett., 27, 1675-1678, https://doi.org/10.1029/1999GL006091.

_- A. Jaramillo, M. M. Gil, N. Quiceno, and R. I. Mantilla, 2001a: Seasonally in ENSO-related precipitation, river discharges, soil moisture, and vegetation index in Colombia. Water Resour. Res., 37, 2169-2178, https://doi.org/10.1029/2000WR900395.

— , W. Rojas, M. L. Quiñones, I. D. Vélez, R. I. Mantilla, D. Ruiz, J. S. Zuluaga, and G. L. Rua, 2001b: Coupling between annual and ENSO timescales in the malaria-climate association in Colombia. Environ. Health Perspect., 109, 489493, https://doi.org/10.2307/3454707.

- and Coauthors, 2005: The diurnal cycle of precipitation in the tropical Andes of Colombia. Mon. Wea. Rev., 133, 228-240, https://doi.org/10.1175/MWR-2853.1.

— D. M. Álvarez, and O. A. Rueda, 2011: Hydro-climatic variability over the Andes of Colombia associated with ENSO: A review of climatic processes and their impact on one of the Earth's most important biodiversity hotspots. Climate Dyn., 36, 2233-2249, https://doi.org/10.1007/s00382-010-0931-y.

_ L. Laramillo, and L. F. Vallejo, 2014: Seasonal precipitation patterns along pathways of South American low-level jets and aerial rivers. Water Resour. Res., 50, 98-118, https://doi.org/ 10.1002/2013WR014087.

Puertas Orozco, O. L., and Y. Carvajal Escobar, 2008: Incidencia de El Niño-Oscilación del Sur en la precipitación y la temperatura del aire en colombia, utilizando el Climate Explorer. Rev. Cient. Ing. Desarrollo, 23, 104-118.

Ramirez, V. H., and A. Jaramillo, 2009: Relación entre el índice oceánico de El Niño y la lluvia en la región Andina central de Colombia. Cenicafé, 60, 161-172.

Ramos da Silva, R., D. Werth, and R. Avissar, 2008: Regional impacts of future land-cover changes on the Amazon basin wet-season climate. J. Climate, 21, 1153-1170, https://doi.org/ 10.1175/2007JCLI1304.1.

Rasmusson, E. M., and J. M. Wallace, 1983: Meteorological aspects of the El Niño/Southern Oscillation. Science, 222, 1195-1202, https://doi.org/10.1126/science.222.4629.1195.

R Core Team, 2018: R: A Language and Environment for Statistical Computing. R Foundation for Statistical Computing, https:// www.R-project.org/.

Restrepo, J. D., and B. Kjerfve, 2000: Magdalena river: Interannual variability (1975-1995) and revised water discharge and sediment load estimates. J. Hydrol., 235, 137-149, https://doi.org/ 10.1016/S0022-1694(00)00269-9.

Roe, G. H., 2005: Orographic precipitation. Annu. Rev. Earth Planet. Sci., 33, 645-671, https://doi.org/10.1146/annurev.earth. 33.092203.122541.

Rogers, J. C., 1981: The North Pacific Oscillation. J. Climatol., 1, 39-57, https://doi.org/10.1002/joc.3370010106.

Rolim, S. G., R. M. Jesus, H. E. M. Nascimento, H. T. Z. do Couto, and J. Q. Chambers, 2005: Biomass change in an Atlantic tropical moist forest: The ENSO effect in permanent sample plots over a 22-year period. Oecologia, 142, 238-246, https:// doi.org/10.1007/s00442-004-1717-x.

Romero, C. C., G. A. Baigorria, and L. Stroosnijder, 2007: Changes of erosive rainfall for El Niño and La Niña years in the northern Andean highlands of Peru. Climatic Change, 85, 343356, https://doi.org/10.1007/s10584-007-9301-0.

Ropelewski, C. F., and M. S. Halpert, 1987: Global and regional scale precipitation patterns associated with the El Niño/Southern Oscillation. Mon. Wea. Rev., 115, 1606-1626, https://doi.org/10.1175/ 1520-0493(1987)115\%3C1606:GARSPP\%3E2.0.CO;2.

Ryan, J. A., and J. M. Ulrich, 2017: xts: eXtensible time series, version 0.12-0. R package, https://CRAN.R-project.org/package=xts.

Santoso, A., M. J. McPhaden, and W. Cai, 2017: The defining characteristics of ENSO extremes and the strong 2015/2016 El Niño. Rev. Geophy., 55, 1079-1129, https://doi.org/10.1002/ 2017RG000560.

Saylor, J. E., A. Mora, B. K. Horton, and J. Nie, 2009: Controls on the isotopic composition of surface water and precipitation in the Northern Andes, Colombian Eastern Cordillera. Geochim. Cosmochim. Acta, 73, 6999-7018, https://doi.org/10.1016/ j.gca.2009.08.030.

Shepherd, J. M., 2005: A review of current investigations of urbaninduced rainfall and recommendations for the future. Earth Interact., 9, https://doi.org/10.1175/EI156.1.

Singhrattna, N., B. Rajagopalan, M. Clark, and K. K. Kumar, 2005: Seasonal forecasting of Thailand summer monsoon rainfall. Int. J. Climatol., 25, 649-664, https://doi.org/10.1002/joc.1144. 
Spearman, C., 1904: The proof and measurement of association between two things. Amer. J. Psychol., 15, 72-101, https:// doi.org/10.2307/1412159.

Suarez, M. L., L. Ghermandi, and T. Kitzberger, 2004: Factors predisposing episodic drought-induced tree mortality in Nothofagus-Site, climatic sensitivity and growth trends. J. Ecol., 92, 954-966, https://doi.org/10.1111/j.1365-2745. 2004.00941.x.

Suárez-Vidal, E., L. Sampedro, and R. Zas, 2017: Is the benefit of larger seed provisioning on seedling performance greater under abiotic stress? Environ. Exp. Bot., 134, 45-53, https:// doi.org/10.1016/j.envexpbot.2016.11.001.

Thornton, P. K., P. J. Ericksen, M. Herrero, and A. J. Challinor, 2014: Climate variability and vulnerability to climate change: A review. Global Change Biol., 20, 3313-3328, https://doi.org/ 10.1111/gcb.12581.

Torrence, C., and G. P. Compo, 1998: A practical guide to wavelet analysis. Bull. Amer. Meteor. Soc., 79, 61-78, https://doi.org/ 10.1175/1520-0477(1998)079<0061:APGTWA >2.0.CO;2.

Trapletti, A., and K. Hornik, 2017: tseries: Time series analysis and computational finance, version 0.10-47. R package, https:// CRAN.R-project.org $/$ package $=$ tseries .

Ulloa, C. U., and Coauthors, 2017: An integrated assessment of the vascular plant species of the Americas. Science, 358, 16141617, https://doi.org/10.1126/science.aao0398.

Uscátegui, A. L.-G., 1992: Geología e Hidrogeología de Santafé de Bogotá y su Sabana. VII Jornada Geotécnicas de la Ingeniería de Colombia, Bogotá, Colombia, Sociedad Colombiana de Ingenieros-Sociedad Colombiana de Geotécnia, https:// www.yumpu.com/es/document/view/14338559/geologia-ehidrogeologia-de-santafe-de-bogota-y-su-logemin-sa.

Vargas, G., Y. Hernández, and J. D. Pabón, 2018: La Niña event 2010-2011: Hydroclimatic effects and socioeconomic impacts in Colombia. Climate Change, Extreme Events and Disaster Risk Reduction, S. Mal, R. Singh, and C. Huggel, Eds., Sustainable Development Goals, Springer, 217-232, https:// link.springer.com/chapter/10.1007/978-3-319-56469-2_15.

Velandia, C. C. L., 2016: Análisis de la distribución espacial y temporal de la precipitación en la cuenca del Río Chicú, Sabana de Bogotá, Colombia. Persp. Geogr.: Rev. Programa Estud. Posgrado Geogr., 21, 63-90, https://dialnet.unirioja.es/ servlet $/$ articulo? codigo $=5626919$.
Vizy, E. K., and K. H. Cook, 2007: Relationship between Amazon and high Andes rainfall. J. Geophys. Res., 112, https://doi.org/ 10.1029/2006JD007980.

Waylen, P., and G. Poveda, 2002: El Niño-Southern Oscillation and aspects of western South American hydro-climatology. Hydrol. Processes, 16, 1247-1260, https://doi.org/10.1002/ hyp.1060.

Webb, E. J., 2017: A reanalysis of the extended multivariate ENSO index (MEI.ext) and comparison of the 1877-78 and 2015-16 El Niño events. 16th Annual Student Conf., Seattle, WA, Amer. Meteor. Soc., S204, https://ams.confex.com/ams/97Annual/ webprogram/Paper317006.html.

Westfall, P. H., 2014: Kurtosis as peakedness, 1905-2014. R.I.P. Amer Stat., 68, 191-195, https://doi.org/10.1080/00031305.2014.917055.

Williamson, G. B., W. F. Laurance, A. A. Oliveira, P. Delamônica, C. Gascon, T. E. Lovejoy, and L. Pohl, 2000: Amazonian tree mortality during the $1997 \mathrm{El}$ Niño drought. Conserv. Biol., 14, 1538-1542, https://doi.org/10.1046/j.1523-1739.2000.99298.x.

Wolter, K., and M. S. Timlin, 1993: Monitoring ENSO in COADS with a seasonally adjusted principal component index. Proc. 17th Climate Diagnostics Workshop, Norman, OK, University of Oklahoma, 52-57.

—, and _ 2011: El Niño/Southern Oscillation behaviour since 1871 as diagnosed in an extended multivariate ENSO index (MEI.ext). Int. J. Climatol., 31, 1074-1087, https://doi.org/ $10.1002 /$ joc. 2336 .

Worden, J., and Coauthors, 2007: Importance of rain evaporation and continental convection in the tropical water cycle. Nature, 445, 528-532, https://doi.org/10.1038/nature05508.

Yeh, S.-W., and Coauthors, 2018: ENSO atmospheric teleconnections and their response to greenhouse gas forcing. Rev. Geophys., 56, 185-206, https://doi.org/10.1002/2017RG000568.

Zambrano-Bigiarini, M., 2017: hydroTSM: Time Series Management, Analysis and Interpolation for Hydrological Modelling, version 0.5-1. R package, https://github.com/hzambran/ hydroTSM.

Zeileis, A., and G. Grothendieck, 2005: Zoo: S3 infrastructure for regular and irregular time series. J. Stat. Software, 14, 1-27, https://doi.org/10.18637/jss.v014.i06.

Zhou, J., and K.-M. Lau, 2001: Principal modes of interannual and decadal variability of summer rainfall over South America. Int. J. Climatol., 21, 1623-1644, https://doi.org/10.1002/joc.700. 